\title{
Explosion Characteristics of Flammable Organic Vapors in Nitrous Oxide Atmosphere
}

\author{
Yusuke Koshiba*, Tomihisa Takigawa, Yusaku Matsuoka, Hideo Ohtani \\ Faculty of Engineering, Yokohama National University, 79-5 Tokiwadai, Hodogaya-ku, Yokohama 240-8501, Japan \\ *Corresponding author: Telephone number: +81-45-339-3985 \\ Fax number: +81-45-339-3985 \\ E-mail address: ykoshiba@ynu.ac.jp \\ Complete postal address: 79-5 Tokiwadai, Hodogaya-ku, Yokohama \\ 240-8501, Japan
}

\section{Abstract}

Despite unexpected explosion accidents caused by nitrous oxide have occurred, few systematic

studies have been reported on explosion characteristics of flammable gases in nitrous oxide atmosphere compared to those in air or oxygen. The objective of this paper is to characterize explosion properties of mixtures of $n$-pentane, diethyl ether, diethylamine, or $n$-butyraldehyde with nitrous oxide and nitrogen using three parameters: explosion limit, peak explosion pressure, and time to the peak explosion pressure. Then, similar mixtures of $n$-pentane, diethyl ether, diethylamine, or $n$-butyraldehyde with oxygen and nitrogen were prepared to compare their explosion characteristics with the mixtures containing nitrous oxide. The explosion experiments were performed in a cylindrical vessel at atmospheric pressure and room temperature. The measurements showed that explosion ranges of the mixtures containing nitrous oxide were narrow compared to those of the 
mixtures containing oxygen. On the other hand, the maximum explosion pressures of the mixtures containing nitrous oxide were higher than those of the mixtures containing oxygen. Moreover, our experiments revealed that these mixtures differed in equivalence ratios at which the maximum explosion pressures were observed: the pressures of the mixtures containing nitrous oxide were observed at stoichiometry; in contrast, those of the mixtures containing oxygen were found at fuel-rich area. Chemical equilibrium calculations confirmed these behaviors.

Keywords: Nitrous oxide; Explosion limit; Explosion pressure, Chemical equilibrium calculation, Organic vapor

\section{Introduction}

Nitrous oxide $\left(\mathrm{N}_{2} \mathrm{O}\right.$, a transparent and colorless gas at atmospheric pressure and room temperature) has been widely employed in semiconductor and electronics industries [1-5]. Moreover, $\mathrm{N}_{2} \mathrm{O}$ is used as a rocket propellant [6] since $\mathrm{N}_{2} \mathrm{O}$ acts as an oxidizer. $\mathrm{N}_{2} \mathrm{O}$ is a beneficial chemical compound; however, a number of unexpected accidents relating to $\mathrm{N}_{2} \mathrm{O}$ occurred in Japan $[7,8]$.

This is because $\mathrm{N}_{2} \mathrm{O}$ supports combustion and decomposes exothermally to oxygen $\left(\mathrm{O}_{2}\right)$ and nitrogen $\left(\mathrm{N}_{2}\right)$ under high temperatures or pressures (Eq. 1). 


$$
\mathrm{N}_{2} \mathrm{O} \rightarrow 1 / 2 \mathrm{O}_{2}+\mathrm{N}_{2}, \quad \Delta H=-82.1 \mathrm{~kJ} / \mathrm{mol}
$$

Many studies on explosion characteristics of flammable gases and vapors blended with air or $\mathrm{O}_{2}$ have been reported [9-20]. Few systematic studies, however, have been reported on the explosion characteristics of the flammable gases with $\mathrm{N}_{2} \mathrm{O}$ [21-23]. To investigate explosion characteristics of the flammable mixture is essential because, in general, evaluation of the quantitative explosion-risk assessment requires the characterization of the explosion hazard of a flammable mixture.

The objective of the present study is to investigate explosion characteristics of volatile organic vapors (n-pentane $\left(n-\mathrm{C}_{5} \mathrm{H}_{12}\right)$, diethyl ether $\left(\mathrm{Et}_{2} \mathrm{O}\right)$, diethylamine $\left(\mathrm{Et}_{2} \mathrm{NH}\right)$, or $n$-butyraldehyde (n-PrCHO)) with $\mathrm{N}_{2} \mathrm{O}$. Explosion characteristics of these fuels having the structure of a five-membered normal chain have not been measured in $\mathrm{N}_{2} \mathrm{O}$ atmosphere. We, hence, chose $n$-pentane, diethyl ether, diethylamine, $n$-butyraldehyde as fuels. Mixtures containing $\mathrm{N}_{2} \mathrm{O}$ $\left(n-\mathrm{C}_{5} \mathrm{H}_{12} / \mathrm{N}_{2} \mathrm{O} / \mathrm{N}_{2}, \quad \mathrm{Et}_{2} \mathrm{O} / \mathrm{N}_{2} \mathrm{O} / \mathrm{N}_{2}, \mathrm{Et}_{2} \mathrm{NH} / \mathrm{N}_{2} \mathrm{O} / \mathrm{N}_{2}\right.$, and $\left.n-\mathrm{PrCHO} / \mathrm{N}_{2} \mathrm{O} / \mathrm{N}_{2}\right)$ were prepared. We examined whether or not these mixtures exploded by measuring their explosion pressures. These mixtures were characterized using three parameters: explosion limit, observed peak explosion pressure, and time to the peak explosion pressure. The reason for the use of these parameters is that the explosion limit, the time to the peak explosion pressure and the peak explosion pressure allow 
the evaluation of explosion sensitivity and explosion impact of the mixtures. On the other hand, mixtures containing $\mathrm{O}_{2}\left(n-\mathrm{C}_{5} \mathrm{H}_{12} / \mathrm{O}_{2} / \mathrm{N}_{2}, \mathrm{Et}_{2} \mathrm{O} / \mathrm{O}_{2} / \mathrm{N}_{2}, \mathrm{Et}_{2} \mathrm{NH} / \mathrm{O}_{2} / \mathrm{N}_{2}\right.$, and $\left.n-\mathrm{PrCHO} / \mathrm{O}_{2} / \mathrm{N}_{2}\right)$ were prepared and evaluated in the same way as the mixtures containing $\mathrm{N}_{2} \mathrm{O}$. Comparisons of the explosion characteristics between the mixtures containing $\mathrm{N}_{2} \mathrm{O}$ and $\mathrm{O}_{2}$ were made.

\section{Experimental}

2.1. Chemicals and gases

$n-\mathrm{C}_{5} \mathrm{H}_{12}, \mathrm{Et}_{2} \mathrm{O}, \mathrm{Et}_{2} \mathrm{NH}$, and $n$-PrCHO (Kanto Chemical Co., Inc., Japan) used were of reagent grade $(>99.5 \%)$. These chemicals were treated over molecular sieves in order to remove a trace amount of water. All commercially available gases $\left(\mathrm{N}_{2} \mathrm{O}, \mathrm{O}_{2}\right.$, and $\left.\mathrm{N}_{2}\right)$ were employed as-received. The purity of these gases was $99.99 \%$ or more.

\subsection{Apparatus}

Figure 1 illustrates the schematic diagram of the explosion apparatus used in this study. Experimental apparatus consisted of a closed cylindrical explosion vessel, tubes, and a vacuum pump. The explosion vessel $[24,25]$ made of stainless steel measured $120 \mathrm{~mm}$ in height by 100 
$\mathrm{mm}$ in diameter by $5.0 \mathrm{~mm}$ in thickness. The internal volume of the explosion vessel was hence approximately $9.4 \times 10^{-4} \mathrm{~m}^{3}(0.94 \mathrm{~L})$.

The explosion vessel was equipped with two pressure transducers, a fan, and a couple of tungsten electrodes. The pressure transducer (PGM-H, Kyowa Electronic Instruments Co., LTD., Japan) which was located on the side of the explosion vessel was used to observe explosion pressure. Another pressure transducer (PTI-S, Swagelok, USA) which was placed on the top of the explosion vessel was used to measure partial pressure when the gases were introduced. The dimensions of the electrodes were $1.0 \mathrm{~mm}$ in diameter by $45.0 \mathrm{~mm}$ in length. The tips of the two electrodes were located about the center of the explosion vessel. The gap of the electrodes was fixed at $10.0 \mathrm{~mm}$. The fan which was located on the top of the explosion vessel and the tubes were made of stainless steel.

\subsection{Procedures}

All explosion experiments were conducted in the explosion vessel at atmospheric pressure and room temperature as follows: first, the explosion vessel was sufficiently evacuated to high vacuum using the vacuum pump. A fuel was introduced into the vacuumed vessel by evaporating the fuel in the recovery flask shown in Fig. 1. Then, the vessel was supplied with the oxidizer gas and $\mathrm{N}_{2}$ gas 
to atmospheric pressure by the partial-pressure method. After the introduced gases were mixed well by the use of the fan at $1000 \mathrm{rpm}$ for $60 \mathrm{~s}$, the fan was stopped. An electric-spark discharge was then formed between the electrodes to ignite the mixture. Electric power for the spark was supplied by a neon transformer. The energy was $18 \mathrm{~J}\left(9.0 \times 10^{3} \mathrm{~V}, 20 \mathrm{~mA}, 0.1 \mathrm{~s}\right)$. Pressure history from the pressure transducer was recorded with a personal computer through a strain measuring unit (NR-ST04, Keyence Co., Japan). The maximum sampling frequency of this system was $50 \mathrm{kHz}$. The start timing of the pressure history was completely simultaneous with that of the electric-spark discharge. We determined the mixtures to be explosive when pressure rise over at least $0.01 \mathrm{MPa}$ (10\% of the initial pressure) was observed. The vessel was lastly evacuated for at least 2 min after each run.

\section{Chemical Equilibrium Calculation}

Provided that chemical reaction in a flame achieves equilibrium, the estimation of combustion product composition is possible at the flame temperature because combustion in a premixed flame is homogeneous gas-phase chemical reaction. In fact, owing to their high flame temperatures, the rate of the chemical reaction is sufficiently fast to achieve equilibrium. At a constant temperature, the chemical reaction achieves equilibrium when the free Gibbs energy of the system reaches the 
minimum: chemical equilibrium calculation can provide composition of resultant chemical species at the temperature using minimization of the free Gibbs energy [26].

When the chemical equilibrium calculation for the mixtures containing $\mathrm{N}_{2} \mathrm{O}\left(n-\mathrm{C}_{5} \mathrm{H}_{12} / \mathrm{N}_{2} \mathrm{O}\right.$, $\mathrm{Et}_{2} \mathrm{O} / \mathrm{N}_{2} \mathrm{O}$, and $\mathrm{Et}_{2} \mathrm{NH} / \mathrm{N}_{2} \mathrm{O}$ ) and the $\mathrm{Et}_{2} \mathrm{NH} / \mathrm{O}_{2}$ mixture were performed, the following 34 chemical species were considered as products in each flame: $\mathrm{CO}, \mathrm{CO}_{2}, \mathrm{C}, \mathrm{C}_{2}, \mathrm{C}_{3}, \mathrm{C}_{4}, \mathrm{C}_{5}, \mathrm{CH}, \mathrm{CH}_{2}, \mathrm{CH}_{3}, \mathrm{CH}_{4}$, $\mathrm{C}_{2} \mathrm{H}_{2}, \mathrm{C}_{2} \mathrm{H}_{4}, \mathrm{C}_{2} \mathrm{H}_{5}, \mathrm{C}_{2} \mathrm{H}_{6}, \mathrm{C}_{6} \mathrm{H}_{6}, \mathrm{HCO}, \mathrm{OH}, \mathrm{H}, \mathrm{H}_{2}, \mathrm{HO}_{2}, \mathrm{H}_{2} \mathrm{O}, \mathrm{H}_{2} \mathrm{O}_{2}, \mathrm{O}, \mathrm{O}_{2}$, the fuel $\left(n-\mathrm{C}_{5} \mathrm{H}_{12}, \mathrm{Et}_{2} \mathrm{O}\right.$, or $\mathrm{Et}_{2} \mathrm{NH}$ ), $\mathrm{CN}, \mathrm{N}, \mathrm{N}_{2}, \mathrm{NO}, \mathrm{NO}_{2}, \mathrm{~N}_{2} \mathrm{O}, \mathrm{NH}, \mathrm{HNO}$, while for the calculation for mixtures without a "N" atom $\left(n-\mathrm{C}_{5} \mathrm{H}_{12} / \mathrm{O}_{2}\right.$ or $\left.\mathrm{Et}_{2} \mathrm{O} / \mathrm{O}_{2}\right)$ the following 26 chemical species were considered as products: $\mathrm{CO}, \mathrm{CO}_{2}, \mathrm{C}, \mathrm{C}_{2}, \mathrm{C}_{3}, \mathrm{C}_{4}, \mathrm{C}_{5}, \mathrm{CH}, \mathrm{CH}_{2}, \mathrm{CH}_{3}, \mathrm{CH}_{4}, \mathrm{C}_{2} \mathrm{H}_{2}, \mathrm{C}_{2} \mathrm{H}_{4}, \mathrm{C}_{2} \mathrm{H}_{5}, \mathrm{C}_{2} \mathrm{H}_{6}, \mathrm{C}_{6} \mathrm{H}_{6}, \mathrm{HCO}, \mathrm{OH}, \mathrm{H}, \mathrm{H}_{2}$, $\mathrm{HO}_{2}, \mathrm{H}_{2} \mathrm{O}, \mathrm{H}_{2} \mathrm{O}_{2}, \mathrm{O}, \mathrm{O}_{2}$, the fuel $\left(n-\mathrm{C}_{5} \mathrm{H}_{12}\right.$ or $\left.\mathrm{Et}_{2} \mathrm{O}\right)$.

Chemical equilibrium calculations were performed with CHEMKIN 4.1.1 software [27]. The seven coefficients (a-g) in the following equations were determined by fitting them to data provided from literature [28] using method of least squares because the software does not have thermodynamic data of the fuels.

$C_{p} / \mathrm{R}=\mathrm{a}+\mathrm{b} T+\mathrm{c} T^{2}+\mathrm{d} T^{3}+\mathrm{e} T^{4}$

$H / \mathrm{R}=\mathrm{a} T+\mathrm{b} T^{2} / 2+\mathrm{c} T^{3} / 3+\mathrm{d} T^{4} / 4+\mathrm{e} T^{5} / 5+\mathrm{f}$

$S / \mathrm{R}=\mathrm{a} \ln T+\mathrm{b} T+\mathrm{c} T^{2} / 2+\mathrm{d} T^{3} / 3+\mathrm{e} T^{4} / 4+\mathrm{g}$ 
where $C_{p}, H, S, \mathrm{R}$, and $T$ are heat capacity at constant pressure, molar enthalpy, molar entropy, gas constant, and temperature, respectively.

The initial conditions for these chemical equilibrium calculations were set to $1.0 \mathrm{~atm}$ and 298.15 K.

\section{Results and Discussion}

No obvious pressure rises were observed when pure $\mathrm{N}_{2} \mathrm{O}$ had been provided with the energy of $18 \mathrm{~J}$ at atmospheric pressure.

Figure 2 depicts a typical pressure history observed in our experiments. The top panel displays the full range of a pressure history provided from the pressure transducer. The mixtures was ignited at $0 \mathrm{~s}$. The bottom panel represents a zoomed in portion of the data. The black and white left-right arrows in the bottom panel express pressure of the sharp peak (SP) and time to the SP, and pressure of the broad peak (BP) and time to the BP, respectively.

The pressure history consisted of two peaks: one SP and one BP. The SP was always accompanied by the BP: the SP have not been observed solely in this study.

In order to clarify the behavior of these peaks, the peak pressures of the SPs and BPs are plotted 
against the time to the peak pressure (Fig. 3a (near-LEL (lower explosion limit)), Fig. $3 b$ (stoichiometric condition)). The error bars determined from four replicate experiments represent one standard deviation. Figures 3a, 3b show that the peak pressures of the SPs (black symbols) were evidently larger than usual explosion pressure. Comparing the SPs with the BPs (gray symbols) revealed that: (1) the variability of the BPs was smaller sufficiently; and (2) the SPs showed low reproducibility, similarly to other researcher's studies [21].

It is likely that the SPs were electrical noise because: (1) the SPs showed relatively higher explosion pressures even at LELs of these mixtures; and (2) the SPs were observed in explosion tests for methane / air mixtures in the identical vessel used in the present study.

Hence, we analyzed the BPs not the SPs in the following sections. It was possible that the SP affected the behavior of the BP because the SP was observed during the growth of the BP. The observation of the shape of these peaks, however, indicated that the BP was probably unsusceptible to the SP. Detailed study on the SPs must be required.

\subsection{Explosion limit}

Figure $4 \mathrm{a}$ shows the triangular explosion diagram of the $n-\mathrm{C}_{5} \mathrm{H}_{12} / \mathrm{N}_{2} \mathrm{O} / \mathrm{N}_{2}$ mixture. The closed circles and open triangles in this figure denote explosive and non-explosive mixtures, respectively. 
The solid and dashed lines illustrate boundaries of the explosive area of the mixture and a stoichiometric line, respectively. As can be seen from Fig. 4a, the lower boundary was almost linear and horizontal, and the upper boundary was almost linear.

The triangular explosion diagram of the $\mathrm{Et}_{2} \mathrm{O} / \mathrm{N}_{2} \mathrm{O} / \mathrm{N}_{2}$ mixture is shown in Fig. 4b. The lower boundary was nearly linear and slightly increased with a decrease in $\mathrm{N}_{2} \mathrm{O}$ concentration. In contrast to the lower boundary, the upper boundary slightly curved.

Figures $4 \mathrm{c}$ and $4 \mathrm{~d}$ are the triangular explosion diagram of the $\mathrm{Et}_{2} \mathrm{NH} / \mathrm{N}_{2} \mathrm{O} / \mathrm{N}_{2}$ and the $n$-PrCHO/ $\mathrm{N}_{2} \mathrm{O} / \mathrm{N}_{2}$ mixtures, respectively. In Fig. 4d, upper explosion limit (UEL) for $n-\mathrm{PrCHO} / \mathrm{N}_{2} \mathrm{O} / \mathrm{N}_{2}$ could not be determined since the vapor pressure of $n-\mathrm{PrCHO}$ is insufficient at room temperature.

Triangular explosion diagrams of the mixtures containing $\mathrm{O}_{2}$ were compared with those of the mixtures containing $\mathrm{N}_{2} \mathrm{O}$. Figure 5a shows the triangular explosion diagram of the $n-\mathrm{C}_{5} \mathrm{H}_{12} / \mathrm{O}_{2} / \mathrm{N}_{2}$ mixture. As shown in Fig. 5a, the lower boundary was almost linear and horizontal, and the upper boundary was almost linear.

Shown in Fig. $5 b$ is the triangular explosion diagram of the $\mathrm{Et}_{2} \mathrm{O} / \mathrm{O}_{2} / \mathrm{N}_{2}$ mixture. The lower boundary was almost linear and horizontal. This mixture was unique among the other mixtures in the shape of explosion diagram: the upper boundary was widely curved.

Figures $5 \mathrm{c}$ and $5 \mathrm{~d}$ are the triangular explosion diagram of the $\mathrm{Et}_{2} \mathrm{NH} / \mathrm{N}_{2} \mathrm{O} / \mathrm{N}_{2}$ and the 
$n$-PrCHO/ $\mathrm{N}_{2} \mathrm{O} / \mathrm{N}_{2}$ mixtures, respectively. In these figures, UEL of $\mathrm{Et}_{2} \mathrm{NH}_{2} / \mathrm{N}_{2} \mathrm{O} / \mathrm{N}_{2}$ and $n-\mathrm{PrCHO} / \mathrm{N}_{2} \mathrm{O} / \mathrm{N}_{2}$ could not be determined as well as the corresponding mixtures containing $\mathrm{N}_{2} \mathrm{O}$.

This experimental study provided the LELs, UELs, and peak concentrations for these mixtures (see Table 1). Comparison of these values for the mixtures containing $\mathrm{N}_{2} \mathrm{O}$ with the mixtures containing $\mathrm{O}_{2}$ showed that: (1) an explosion range of the mixtures containing $\mathrm{N}_{2} \mathrm{O}$ was narrow compared to that of the corresponding mixture containing $\mathrm{O}_{2}$ (Entries 1 vs. 5, 2 vs. 6, 3 vs. 7, 4 vs. 8); and (2) the peak concentrations of mixtures containing $\mathrm{N}_{2} \mathrm{O}$ were lower than those of the corresponding mixtures containing $\mathrm{O}_{2}$ (Entries 1 vs. 5, 2 vs. 6, 3 vs. 7, 4 vs. 8). By comparing the explosion ranges among these mixtures, it can be seen that the explosion ranges of $\mathrm{Et}_{2} \mathrm{O}$ were widest. In particular, notwithstanding $\mathrm{Et}_{2} \mathrm{O} / \mathrm{N}_{2} \mathrm{O} / \mathrm{N}_{2}$ mixture showed the explosion range of $0.8-20.0$ vol. $\%$ (Entry 2), $\mathrm{Et}_{2} \mathrm{O} / \mathrm{O}_{2} / \mathrm{N}_{2}$ mixture exhibited a remarkably wide explosion range (0.8 - 54.0 vol.\%, Entry 6). It is well-known that $\mathrm{Et}_{2} \mathrm{O}$ reacts mildly with an oxidizer to form cool flame under extremely fuel-rich conditions. When the cool flame is formed, the pressure rise is hardly observed because of its low temperatures. However, the cool flame can develop into normal flame involving pressure rise [29]. Hence, in our experiments, the UEL of $\mathrm{Et}_{2} \mathrm{O} / \mathrm{O}_{2} / \mathrm{N}_{2}$ mixture was influenced by the cool flame, resulting in the significant increase in the UEL of the mixture. In contrast, the UEL of $\mathrm{Et}_{2} \mathrm{O} / \mathrm{N}_{2} \mathrm{O} / \mathrm{N}_{2}$ mixture did not appear to be influenced by the cool flame. The cause of the difference is not clear; however, the difference possibly results from the ease with which the cool 
flame is formed.

These experiments concerning the flammability limit showed that the mixtures containing $\mathrm{O}_{2}$ were more hazardous compared to the mixtures containing $\mathrm{N}_{2} \mathrm{O}$ under our experimental conditions.

Here we refer to the device used in this study. Many early studies have investigated explosion characteristics using various devices and methods [30]. However, it is well-known that explosion characteristics (e.g. explosion limit) can depend on experimental system and conditions such as a diameter of vessel, ignition energy, initial temperature, and pressure. Flame propagation occurs by being transferred energy from burnt layer to unburned layer. The decrease in the energy, hence, affects explosion characteristics (e.g. explosion limit) of flammable mixtures. In general, the explosion test requires large diameter of an explosion vessel which can ignore the influence because a vessel wall has a quenching effect. With regard to a volatile flammable substance with air or air/inert gas, standard test methods [31-33] were recently used to determine their explosion characteristics.

The shape and volume of the explosion vessel used in our study were different from those used in the standards. The relative high ratio of surface area to volume of the vessel due to smaller vessel volume may increase the energy lost per unit volume. However, it is known that explosion limits of almost all flammable mixtures hardly changed when an explosion vessel has $>5 \mathrm{~cm}$ in diameter [34]. In fact, we confirmed that an explosion range of $\mathrm{CH}_{4} /$ air was determined to be 5.0-15.3 vol. \% using 
our explosion vessel, showing that the explosion range was comparable to that shown in lit. [35] (5.0

-14.9 vol. \%). Hence, we consider that the energy loss is small.

4.2. Explosion-pressure analysis using peak explosion pressures and times to the peak explosion pressures

The peak explosion pressures and the times to the peak explosion pressures of these mixtures are plotted against concentration of the fuel $\left(n-\mathrm{C}_{5} \mathrm{H}_{12}, \mathrm{Et}_{2} \mathrm{O}\right.$, or $\left.\mathrm{Et}_{2} \mathrm{NH}\right)$ when $\mathrm{N}_{2}$ concentration is fixed at 30.0 vol. \%. Figures $6 \mathrm{a}, 6 \mathrm{~b}$, and $6 \mathrm{c}$ show the profiles of $n-\mathrm{C}_{5} \mathrm{H}_{12} / \mathrm{N}_{2} \mathrm{O} / \mathrm{N}_{2}, \mathrm{Et}_{2} \mathrm{O} / \mathrm{N}_{2} \mathrm{O} / \mathrm{N}_{2}$, and $\mathrm{Et}_{2} \mathrm{NH} / \mathrm{N}_{2} \mathrm{O} / \mathrm{N}_{2}$ mixtures, respectively. Figures $7 \mathrm{a}, 7 \mathrm{~b}$, and $7 \mathrm{c}$ depict the profiles of $n-\mathrm{C}_{5} \mathrm{H}_{12} / \mathrm{O}_{2} / \mathrm{N}_{2}$, $\mathrm{Et}_{2} \mathrm{O} / \mathrm{O}_{2} / \mathrm{N}_{2}$, and $\mathrm{Et}_{2} \mathrm{NH} / \mathrm{O}_{2} / \mathrm{N}_{2}$ mixtures, respectively. The profile of $n$-PrCHO mixtures $\left(n-\mathrm{PrCHO} / \mathrm{N}_{2} \mathrm{O} / \mathrm{N}_{2}\right.$ and $n-\mathrm{PrCHO} / \mathrm{O}_{2} / \mathrm{N}_{2}$ ) could not be obtained since the vapor pressure for $n$-PrCHO is insufficient in the experimental conditions.

As mentioned above, these analyses were performed using the BPs. The gray area and dashed line in these figures denote the non-explosive area and the stoichiometric concentration line, respectively. These results show that the peak explosion pressure (०) gradually increased consistently with the concentration of the fuel, and then approached a maximum at about the stoichiometric concentration, and subsequently decreased gradually with an increase in the 
concentration of the fuel although a few differences in the behavior were observed among these mixtures. On the other hand, the time to the peak explosion pressure $(\mathbf{\Delta})$ decreased with an increase in the fuel concentration, and then reached a plateau at about the stoichiometric concentration, and subsequently gently increased in keeping with the fuel concentration.

Table 2 shows their maximum peak pressures, the fuel concentrations at which the maximum peak pressures were observed $\left(\mathrm{C}_{\mathrm{f}}\right)$, and stoichiometric concentrations of the fuels. The maximum peak pressures of $n-\mathrm{C}_{5} \mathrm{H}_{12} / \mathrm{N}_{2} \mathrm{O} / \mathrm{N}_{2}, \mathrm{Et}_{2} \mathrm{O} / \mathrm{N}_{2} \mathrm{O} / \mathrm{N}_{2}$, and $\mathrm{Et}_{2} \mathrm{NH} / \mathrm{N}_{2} \mathrm{O} / \mathrm{N}_{2}$ were determined to be 1.72 , 1.70, and 1.74 MPa, respectively (Entries 1-3). On the other hand, the maximum peak pressures of $n-\mathrm{C}_{5} \mathrm{H}_{12} / \mathrm{O}_{2} / \mathrm{N}_{2}, \mathrm{Et}_{2} \mathrm{O} / \mathrm{O}_{2} / \mathrm{N}_{2}$, and $\mathrm{Et}_{2} \mathrm{NH} / \mathrm{O}_{2} / \mathrm{N}_{2}$ were found to be $1.56,1.46$, and $1.63 \mathrm{MPa}$, respectively (Entries 4-6). The results revealed that the maximum peak pressures of the mixtures containing $\mathrm{N}_{2} \mathrm{O}$ were high compared to those of the mixtures containing $\mathrm{O}_{2}$ (Entries 1 vs. 4, 2 vs. 5, and 2 vs. 6). With regard to $\mathrm{C}_{\mathrm{f}}$, the maximum peak pressures of the mixtures containing $\mathrm{N}_{2} \mathrm{O}$ were observed at near stoichiometric concentrations or fuel-lean conditions (Entries 1-3); in contrast, those of the mixtures containing $\mathrm{O}_{2}$ were observed at fuel-rich conditions (Entries 4-6). In order to make clear these results, the chemical equilibrium calculations were performed in the next section.

4.3. Chemical equilibrium calculation 
The chemical equilibrium calculations for the mixtures containing $\mathrm{N}_{2} \mathrm{O}$ showed that the mole fractions of $\mathrm{N}_{2} \mathrm{O}$ were extremely low at any fuel-equivalence ratio $(\phi)$. The result agreed well with the fact that the decomposition reaction of $\mathrm{N}_{2} \mathrm{O}$ occurs under high pressure condition according to Eq. 1. The maximum peak pressures of the mixtures containing $\mathrm{N}_{2} \mathrm{O}$ were high compared to those of mixtures containing $\mathrm{O}_{2}$ because not only explosion pressure but also the pressure originated from decomposition of the excess $\mathrm{N}_{2} \mathrm{O}$ were observed.

Adiabatic flame temperatures (AFTs) and compositions of major chemical species of $n-\mathrm{C}_{5} \mathrm{H}_{12} / \mathrm{N}_{2} \mathrm{O} / \mathrm{N}_{2}$ and $n-\mathrm{C}_{5} \mathrm{H}_{12} / \mathrm{O}_{2} / \mathrm{N}_{2}$ were plotted as a function of $\phi$, respectively (Fig. 8). The results showed that mixtures containing $\mathrm{N}_{2} \mathrm{O}$ and mixtures containing $\mathrm{O}_{2}$ were different in $\phi \mathrm{s}$ at which the $\mathrm{CO}$ curve and the $\mathrm{CO}_{2}$ curve intersected: the point of intersection of the curves of $\mathrm{CO}$ and $\mathrm{CO}_{2}$ of $n-\mathrm{C}_{5} \mathrm{H}_{12} / \mathrm{N}_{2} \mathrm{O} / \mathrm{N}_{2}$ was observed at near stoichiometric concentration $(\phi \approx 1)$; in contrast, the point of intersection of $n-\mathrm{C}_{5} \mathrm{H}_{12} / \mathrm{O}_{2} / \mathrm{N}_{2}$ was found at fuel-lean area $(\phi<1)$.

The amount of $\mathrm{CO}$ chiefly depended on ease of incomplete combustion. This is because in the points of the intersections shown in Fig. 8, there was no significant difference in AFTs of these mixtures, indicating that amounts of $\mathrm{CO}$ produced by thermal dissociation of $\mathrm{CO}_{2}$ [36] were expected to be nearly equivalent. In larger $\phi$ than the point of intersection, the amount of produced $\mathrm{CO}$ exceeded that of $\mathrm{CO}_{2}$, implying that incomplete combustion was promoted.

As mentioned above, a comparison of the points of the intersections revealed that $\phi$ at the 
intersection point of $n-\mathrm{C}_{5} \mathrm{H}_{12} / \mathrm{N}_{2} \mathrm{O} / \mathrm{N}_{2}$ was larger than that $\phi$ at that of $n-\mathrm{C}_{5} \mathrm{H}_{12} / \mathrm{O}_{2} / \mathrm{N}_{2}$. Hence, the results showed that the mixture containing $\mathrm{N}_{2} \mathrm{O}\left(n-\mathrm{C}_{5} \mathrm{H}_{12} / \mathrm{N}_{2} \mathrm{O} / \mathrm{N}_{2}\right)$ underwent more complete combustion than the mixture containing $\mathrm{O}_{2}\left(n-\mathrm{C}_{5} \mathrm{H}_{12} / \mathrm{O}_{2} / \mathrm{N}_{2}\right)$ at about stoichiometry. Moreover, in $\phi \leq$ 1, the presence of excess $\mathrm{N}_{2} \mathrm{O}$ tending to decompose led to observation of a maximum peak pressure at about stoichiometry or fuel-lean conditions.

The calculations confirmed that other mixtures $\left(\mathrm{Et}_{2} \mathrm{O} / \mathrm{N}_{2} \mathrm{O} / \mathrm{N}_{2} v s . \mathrm{Et}_{2} \mathrm{O} / \mathrm{O}_{2} / \mathrm{N}_{2}, \mathrm{Et}_{2} \mathrm{NH} / \mathrm{N}_{2} \mathrm{O} / \mathrm{N}_{2} v s\right.$. $\mathrm{Et}_{2} \mathrm{NH} / \mathrm{O}_{2} / \mathrm{N}_{2}$ ) offered the same behavior as $n-\mathrm{C}_{5} \mathrm{H}_{12} / \mathrm{N}_{2} \mathrm{O} / \mathrm{N}_{2}$ vs. $n-\mathrm{C}_{5} \mathrm{H}_{12} / \mathrm{O}_{2} / \mathrm{N}_{2}$.

\section{Conclusions}

The explosion characteristics of the mixtures containing $\mathrm{N}_{2} \mathrm{O}\left(n-\mathrm{C}_{5} \mathrm{H}_{12} / \mathrm{N}_{2} \mathrm{O} / \mathrm{N}_{2}, \mathrm{Et}_{2} \mathrm{O} / \mathrm{N}_{2} \mathrm{O} / \mathrm{N}_{2}\right.$, $\mathrm{Et}_{2} \mathrm{NH} / \mathrm{N}_{2} \mathrm{O} / \mathrm{N}_{2}$, and $\left.n-\mathrm{PrCHO} / \mathrm{N}_{2} \mathrm{O} / \mathrm{N}_{2}\right)$ and $\mathrm{O}_{2}\left(n-\mathrm{C}_{5} \mathrm{H}_{12} / \mathrm{O}_{2} / \mathrm{N}_{2}, \quad \mathrm{Et}_{2} \mathrm{O} / \mathrm{O}_{2} / \mathrm{N}_{2}, \mathrm{Et}_{2} \mathrm{NH} / \mathrm{O}_{2} / \mathrm{N}_{2}\right.$, and $n-\mathrm{PrCHO} / \mathrm{O}_{2} / \mathrm{N}_{2}$ ) were investigated with their explosion limits, maximum peak pressure, and time to the peak pressures using the cylindrical explosion vessel.

The measurements provided the explosion limits of $n-\mathrm{C}_{5} \mathrm{H}_{12} / \mathrm{N}_{2} \mathrm{O} / \mathrm{N}_{2}, \quad \mathrm{Et}_{2} \mathrm{O} / \mathrm{N}_{2} \mathrm{O} / \mathrm{N}_{2}$, $\mathrm{Et}_{2} \mathrm{NH} / \mathrm{N}_{2} \mathrm{O} / \mathrm{N}_{2}, n-\mathrm{C}_{5} \mathrm{H}_{12} / \mathrm{O}_{2} / \mathrm{N}_{2}$, and $\mathrm{Et}_{2} \mathrm{NH} / \mathrm{O}_{2} / \mathrm{N}_{2}$ mixtures. The results showed that the explosion ranges of the mixtures containing $\mathrm{N}_{2} \mathrm{O}$ were narrow compared to those of the mixtures containing $\mathrm{O}_{2}$. Regarding the mixtures containing $n$-PrCHO $\left(n-\mathrm{PrCHO} / \mathrm{N}_{2} \mathrm{O} / \mathrm{N}_{2}\right.$ and $\left.n-\mathrm{PrCHO} / \mathrm{O}_{2} / \mathrm{N}_{2}\right)$ and 
$\mathrm{Et}_{2} \mathrm{NH} / \mathrm{O}_{2} / \mathrm{N}_{2}$ mixture, our experiments did not allow the determination of their LELs due to the low vapor pressure of the fuels.

On the other hand, a comparison of observed maximum peak pressure revealed that the maximum peak pressures of the mixtures containing $\mathrm{N}_{2} \mathrm{O}$ were high compared to those of the mixtures containing $\mathrm{O}_{2}$. In addition, we made it clear that the maximum peak pressures of the mixtures containing $\mathrm{O}_{2}$ were observed in the region $\phi>1$; in contrast, the maximum peak pressures of the mixtures containing $\mathrm{N}_{2} \mathrm{O}$ were observed at about stoichiometry $(\phi \approx 1)$.

The chemical equilibrium calculations were performed to clarify the behavior. The results demonstrated that: (1) decomposition reaction of excess $\mathrm{N}_{2} \mathrm{O}$ in the mixture occurred at any fuel-equivalence ratio; and (2) the mixtures containing $\mathrm{N}_{2} \mathrm{O}$ underwent complete combustion compared to the mixtures containing $\mathrm{O}_{2}$.

\section{References}

[1] S. Jung, J. Kim, H. Son, S. Hwang, K. Jang, J. Lee, K. Lee, H. Park, K. Kim, J. Yi, Fabrication and characterization of metal-oxide-nitride-oxynitride-polysilicon nonvolatile semiconductor memory device with silicon oxynitride $\left(\mathrm{SiO}_{\mathrm{x}} \mathrm{N}_{\mathrm{y}}\right)$ as tunneling layer on glass, J. App. Phys. 102 (2007), 094502/1-094502/4. 
[2] K.F. Albertin, I. Pereyra, Improved effective charge density in MOS capacitors with PECVD

$\mathrm{SiO}_{\mathrm{x}} \mathrm{N}_{\mathrm{y}}$ dielectric layer obtained at low RF power, J. Non-Cryst. Solids 354 (2008) 2646-2651.

[3] P. Mandracci, C. Ricciardi, Silicon-carbon-oxynitrides grown by plasma-enhanced chemical vapor deposition technique, Thin Solid Films 515 (2007) 7639-7642.

[4] D. Criado, M.I. Alayo, I. Pereyra, M.C.A. Fantini, Structural analysis of silicon oxynitride films deposited by PECVD, Mater. Sci. Eng. B112 (2004) 123-127.

[5] M. Chayania, H. Caquineaua, B. Despaxa, J. Bandetb, R. Berjoanc, Variations in the physico-chemical properties of near-stoichiometric silica deposited from $\mathrm{SiH}_{4}-\mathrm{N}_{2} \mathrm{O}$ and $\mathrm{SiH}_{4}-\mathrm{N}_{2} \mathrm{O}-\mathrm{He}$ radiofrequency discharges, Thin Solid Films 471 (2005) 53-62.

[6] V. Zakirov, M. Sweeting, Nitrous oxide as a rocket propellant, Acta Astronautica 48 (2001) 353-362.

[7] Y. Hashiguchi, Accidents occurred in the semiconductor manufacturing industries and issues for loss prevention, J. High Press. Gas Safety Inst. Jpn. 35 (1998) 782-789.

[8] T. Hirano, Present needs of gases for semiconductor manufacturing and preferable safety management, J. High Press. Gas Safety Inst. Jpn. 35 (1998) 775-781.

[9] C.C. Chen, H.J. Liaw, T.C. Wang, C.Y. Lin, Carbon dioxide dilution effect on flammability limits for hydrocarbons, J. Hazard. Mater. 163 (2009) 795-803.

[10] M.R. Brooks, D.A. Crowl, Flammability envelopes for methanol, ethanol, acetonitrile and 
toluene, J. Loss Prevent. Process Ind. 20 (2007) 144-150.

[11] F.V. den Schoor, F. Norman, L. Tangen, O. S æter, F. Verplaetsen, Explosion limits of mixtures relevant to the production of 1,2-dichloroethane (ethylene dichloride), J. Loss Prevent. Process Ind. 20 (2007) 281-285

[12] S. Kondo, Y. Urano, K. Takizawa, A. Takahashi, K. Tokuhashi, Flammability limits of multi-fluorinated compounds, Fire Safety J. 41 (2006) 46-56.

[13] S.Y. Liao, Q. Cheng, D.M. Jiang, J. Gao., Experimental study of flammability limits of natural gas-air mixture, J. Hazard. Mater. B199 (2005) 81-84.

[14] D.P. Mishra and A. Rahman, An experimental study of flammability limits of LPG/air mixtures, Fuel $82(2003)$ 863-866.

[15] S. Kondo, A. Takahashi, K. Tokuhashi, Experimental exploration of discrepancies in F-number correlation of flammability limits, J. Hazard. Mater. A100 (2003) 27-36.

[16] K.L. Cashdollar, I.A. Zlochower, G.M. Green, Flammability of methane, propane, and hydrogen gases, J. Loss Prevent. Process Ind. 13 (2000) 327-340.

[17] K.J. Liekhus, I.Z. Zlochower, K.L. Cashdollar, S.M. Diordievic, C.A. Loehr, Flammability of gas mixtures containing volatile organic compounds and hydrogen, J. Loss Prevent. Process Ind. 13 (2000) 377-384.

[18] R.T. Pollard, The flammability limits of fluorobenzenes in oxygen and oxygen-nitrogen 
mixtures, Combust. Flame 17 (1971) 337-342.

[19] E.T. McHale, R.W. Geary, G. von Elbe, C. Huggett, Flammability limits of $\mathrm{H}_{2}-\mathrm{O}_{2}$-fluorocarbon mixtures, Combust. Flame 16 (1971) 167-175.

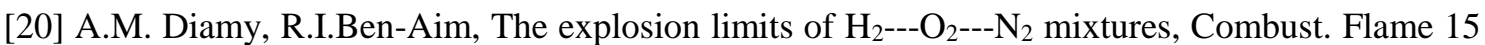
(1970) 207-209.

[21] L. Vandebroek, F.V. den Schoor, F. Verplaetsen, J. Berghmans, H. Winter, E. van’t Oost, Flammability limits and explosion characteristics of toluene-nitrous oxide mixtures, J. Hazard.

Mater. A120 (2005) 57-65.

[22] M. Destriau, On the explosion limits of various combustible gases using nitrous oxide as oxidizer, Combust. Flame 6 (1962) 347-350.

[23] J.H. Coste, C.A. Chaplin, An investigation into the risks of fire or explosion in operating theatres, Bri. J. Anaesth. 14 (1937) 115-129.

[24] H. Ohtani, Flammability limits of silane/perfluorocarbon/nitrogen mixtures, J. Loss Prevent. Process Ind. 17 (2004) 381-383.

[25] H. Ohtani, Experimental study on flammability limits of perfluorocarbons in a fluorine atmosphere, J. Loss Prevent. Process Ind. 17 (2004) 377-379.

[26] G.A. Melhem, A detailed method for estimating mixture flammability limits using chemical equilibrium, Process Safety Prog. 16 (1997) 203-218. 
[27] R.J. Kee, F.M. Rupley, J.A. Miller, M.E. Coltrin, J.F. Grcar, E. Meeks, H.K. Moffat, A.E. Lutz,

G. Dixon-Lewis, M.D. Smooke, J. Warnatz, G.H. Evans, R.S. Larson, R.E. Mitchell, L.R. Petzold,

W.C. Reynolds, M. Caracotsios, W.E. Stewart, P. Glarborg, C. Wang, C.L. McLellan, O. Adigun, W.G. Houf, C.P. Chou, S.F. Miller, P. Ho, P.D. Young, D.J. Young, D.W. Hodgson, M.V. Petrova, and K.V. Puduppakkam, CHEMKIN Release 4.1.1, Reaction Design, San Diego, CA (2007).

[28] M.W. Chase Jr., NIST-JANAF Thermochemicaltables, fourth ed., Part I. Al-Co and Part II, Cr-Zr. J. Phys. Chem. Ref. Data, Monograph No. 9, Springer-Verlag, New York, 1998.

[29] K. Spence, D.T.A. Townend, Nature 155 (1945) 330-331.

[30] L.G. Britton, Two hundred years of flammable limits, Process Safety Prog. 21 (2002) 1-11.

[31] ASTM E 681-04: Standard test method for concentration limits of flammability of chemicals (vapors and gases), vol. 14.02, West Conshohocken, PA, 2009.

[32] EN 1839 method T: Determination of explosion limits of gases and vapours, Sec. 4.1, Brussels, Belgium, 2003.

[33] EN 1839 method B: Determination of explosion limits of gases and vapours, Sec. 4.1, Brussels, Belgium, 2003.

[34] H.F. Coward, G.W. Jones, Limits of flammability of gases and vapors, U. S. Dept. of the Interior, Bureau of mines Bulletin 503, Washington, DC, 1953.

[35] J.M. Kuchta, Investigation of fire and explosion accidents in the chemical, mining, and 
fuel-related industries, U.S. Dept. of the Interior, Bureau of mines, Bulletin 680, Washington,

DC, 1985.

[36] E.S. Fishburne, K.R. Bilwakesh, R. Edse, Gaseous reaction rates at high temperature. I. The dissociation of carbon dioxide, J. Chem. Phys. 45 (1966) 160-166.

\section{Captions to Tables}

Table 1. Explosion limits and peak concentrations of $n-\mathrm{C}_{5} \mathrm{H}_{12} / \mathrm{N}_{2} \mathrm{O} / \mathrm{N}_{2}, \mathrm{Et}_{2} \mathrm{O} / \mathrm{N}_{2} \mathrm{O} / \mathrm{N}_{2}, \mathrm{Et}_{2} \mathrm{NH} / \mathrm{N}_{2} \mathrm{O} / \mathrm{N}_{2}$,

$n-\mathrm{PrCHO} / \mathrm{N}_{2} \mathrm{O} / \mathrm{N}_{2}, n-\mathrm{C}_{5} \mathrm{H}_{12} / \mathrm{O}_{2} / \mathrm{N}_{2}, \mathrm{Et}_{2} \mathrm{O} / \mathrm{O}_{2} / \mathrm{N}_{2}, \mathrm{Et}_{2} \mathrm{NH} / \mathrm{O}_{2} / \mathrm{N}_{2}, n-\mathrm{PrCHO} / \mathrm{O}_{2} / \mathrm{N}_{2}$ mixtures.

Table 2. The summary of Figs. 6 and 7. 


\section{Figure captions}

Fig. 1. A schematic diagram of the explosion apparatus composed of a cylindrical explosion vessel, piping, and a vacuum pump.

Fig. 2. A typical pressure history composed of a sharp and broad signal (the top panel). The zoomed in portion of the data (bottom panel).

Fig. 3a (near-LEL) Peak explosion pressures of the SPs (black symbols) and BPs (gray symbols) vs. times to the peak explosion pressure. The error bars represent standard deviation.

Fig. 3b (stoichiometric condition) Peak explosion pressures of the SPs (black symbols) and BPs (gray symbols) vs. times to the peak explosion pressure. The error bars represent standard deviation.

Fig. 4a. The triangle explosion diagram of $n-\mathrm{C}_{5} \mathrm{H}_{12} / \mathrm{N}_{2} \mathrm{O} / \mathrm{N}_{2}$ mixture; ○: explosive, $\Delta$ : non-explosive.

Fig. 4b. The triangle explosion diagram of $\mathrm{Et}_{2} \mathrm{O} / \mathrm{N}_{2} \mathrm{O} / \mathrm{N}_{2}$ mixture; ०: explosive, $\Delta$ : non-explosive. 
Fig. 4c. The triangle explosion diagram of $\mathrm{Et}_{2} \mathrm{NH} / \mathrm{N}_{2} \mathrm{O} / \mathrm{N}_{2}$ mixture; ○: explosive, $\Delta$ : non-explosive.

Fig. $4 \mathrm{~d}$. The triangle explosion diagram of $n-\mathrm{PrCHO} / \mathrm{N}_{2} \mathrm{O} / \mathrm{N}_{2}$ mixture; $\circ$ : explosive, $\Delta$ :

non-explosive.

Fig. 5a. The triangle explosion diagram of $n-\mathrm{C}_{5} \mathrm{H}_{12} / \mathrm{O}_{2} / \mathrm{N}_{2}$ mixture; ○: explosive, $\Delta$ : non-explosive.

Fig. 5b. The triangle explosion diagram of $\mathrm{Et}_{2} \mathrm{O} / \mathrm{O}_{2} / \mathrm{N}_{2}$ mixture; ○: explosive, $\Delta$ : non-explosive.

Fig. 5c. The triangle explosion diagram of $\mathrm{Et}_{2} \mathrm{NH} / \mathrm{O}_{2} / \mathrm{N}_{2}$ mixture; $\circ$ : explosive, $\Delta$ : non-explosive.

Fig. 5 d. The triangleexplosion diagram of $n-\mathrm{PrCHO} / \mathrm{O}_{2} / \mathrm{N}_{2}$ mixture; ○: explosive, $\Delta$ : non-explosive.

Fig. 6a. Profiles of the peak pressures ( $(\circ)$ and the times to the peak pressures ( $\boldsymbol{\Delta})$ of $n-\mathrm{C}_{5} \mathrm{H}_{12} / \mathrm{N}_{2} \mathrm{O} /$ $\mathrm{N}_{2}$ mixture $\left(\mathrm{N}_{2}\right.$ vol.\% $=30$ vol.\% $)$. The gray areas and the dashed line denote the non-explosive and the stoichiometric concentration line, respectively.

Fig. 6b. Profiles of the peak pressures ( 0 ) and the times to the peak pressures ( $\Delta$ ) of $\mathrm{Et}_{2} \mathrm{O} / \mathrm{N}_{2} \mathrm{O} / \mathrm{N}_{2}$ 
mixture $\left(\mathrm{N}_{2}\right.$ vol. $\%=30$ vol. $\left.\%\right)$.

Fig. 6c. Profiles of the peak pressures $(\circ)$ and the times to the peak pressures $(\boldsymbol{\Delta})$ of $\mathrm{Et}_{2} \mathrm{NH} / \mathrm{N}_{2} \mathrm{O} / \mathrm{N}_{2}$ mixture $\left(\mathrm{N}_{2}\right.$ vol. $\%=30$ vol. $\left.\%\right)$.

Fig. 7a. Profiles of the peak pressures ( $\mathrm{O}$ ) and the times to the peak pressures ( $\boldsymbol{\Delta}$ ) of $n-\mathrm{C}_{5} \mathrm{H}_{12} / \mathrm{O}_{2} / \mathrm{N}_{2}$ mixture $\left(\mathrm{N}_{2}\right.$ vol. $\%=30$ vol. $\left.\%\right)$.

Fig. 7b. Profiles of the peak pressures ( $\left(\right.$ ) and the times to the peak pressures $(\Delta)$ of $\mathrm{Et}_{2} \mathrm{O} / \mathrm{O}_{2} / \mathrm{N}_{2}$ mixture $\left(\mathrm{N}_{2}\right.$ vol. $\%=30$ vol. $\left.\%\right)$.

Fig. 7c. Profiles of the peak pressures ( $(0)$ and the times to the peak pressures $(\Delta)$ of $\mathrm{Et}_{2} \mathrm{NH} / \mathrm{O}_{2} / \mathrm{N}_{2}$ mixture $\left(\mathrm{N}_{2}\right.$ vol. $\%=30$ vol. $\left.\%\right)$.

Fig. 8. Composition of major chemical species (CO: circles, $\mathrm{CO}_{2}$ : squares) and adiabatic flame temperature (gray triangles) plotted as a function of the fuel equivalence ratio $\phi$ of $n-\mathrm{C}_{5} \mathrm{H}_{12} / \mathrm{N}_{2} \mathrm{O}$ (open symbols) and $n$ - $\mathrm{C}_{5} \mathrm{H}_{12} / \mathrm{O}_{2}$ (solid symbols) mixtures. The dashed and solid lines depict point of intersection of $\mathrm{CO}\left(n-\mathrm{C}_{5} \mathrm{H}_{12} / \mathrm{N}_{2} \mathrm{O}\right.$ mixture $)-\mathrm{CO}_{2}\left(n-\mathrm{C}_{5} \mathrm{H}_{12} / \mathrm{N}_{2} \mathrm{O}\right.$ mixture $)$ and $\mathrm{CO}\left(n-\mathrm{C}_{5} \mathrm{H}_{12} / \mathrm{O}_{2}\right.$ 
mixture) $-\mathrm{CO}_{2}\left(n-\mathrm{C}_{5} \mathrm{H}_{12} / \mathrm{O}_{2}\right.$ mixture $)$, respectively. 


\begin{tabular}{ccccc}
\hline Entry & Mixture & $\begin{array}{c}\text { LEL } \\
\text { [vol.\%] }\end{array}$ & $\begin{array}{c}\text { UEL } \\
{[\text { vol.\%] }}\end{array}$ & $\begin{array}{c}\text { Peak } \\
\text { concentration } \\
\text { [vol.\%] }\end{array}$ \\
\hline 1 & $n-\mathrm{C}_{5} \mathrm{H}_{12} / \mathrm{N}_{2} \mathrm{O}$ & 0.8 & 13.8 & 56.8 \\
2 & $\mathrm{Et}_{2} \mathrm{O} / \mathrm{N}_{2} \mathrm{O}$ & 0.8 & 20.0 & 56.2 \\
3 & $\mathrm{Et}_{2} \mathrm{NH} / \mathrm{N}_{2} \mathrm{O}$ & 2.0 & 19.4 & 54.8 \\
4 & $n-\mathrm{PrCHO} / \mathrm{N}_{2} \mathrm{O}$ & 2.2 & $\mathrm{ND}^{\mathrm{a}}$ & 61.6 \\
\hline 5 & $n-\mathrm{C}_{5} \mathrm{H}_{12} / \mathrm{O}_{2}$ & 0.2 & 33.4 & 80.2 \\
6 & $\mathrm{Et}_{2} \mathrm{O} / \mathrm{O}_{2}$ & 1.0 & 54.0 & 85.2 \\
7 & $\mathrm{Et}_{2} \mathrm{NH} / \mathrm{O}_{2}$ & 1.8 & $\mathrm{ND}^{\mathrm{a}}$ & 81.2 \\
8 & $n-\mathrm{PrCHO}_{2} \mathrm{O}_{2}$ & 2.0 & $\mathrm{ND}^{\mathrm{a}}$ & 83.2 \\
\hline
\end{tabular}

${ }^{a}$ ND: not detected

Table 1 


\begin{tabular}{ccccc}
\hline Entry & Mixture & $\begin{array}{c}\text { Maximum } \\
\text { peak pressure } \\
{[\mathrm{MPa}]}\end{array}$ & $\begin{array}{c}\text { Fuel concentration at which } \\
\text { the maximum peak pressure } \\
\text { was observed [vol. \%] }\end{array}$ & $\begin{array}{c}\text { Stoichiometric } \\
\text { concentration of fuel } \\
\text { [vol.\%] }\end{array}$ \\
\hline 1 & $n-\mathrm{C}_{5} \mathrm{H}_{12} / \mathrm{N}_{2} \mathrm{O} / \mathrm{N}_{2}$ & 1.72 & 3.0 & 4.1 \\
2 & $\mathrm{Et}_{2} \mathrm{O} / \mathrm{N}_{2} \mathrm{O} / \mathrm{N}_{2}$ & 1.70 & 4.0 & 5.4 \\
3 & $\mathrm{Et}_{2} \mathrm{NH} / \mathrm{N}_{2} \mathrm{O} / \mathrm{N}_{2}$ & 1.74 & 5.0 & 4.8 \\
4 & $n-\mathrm{C}_{5} \mathrm{H}_{12} / \mathrm{O}_{2} / \mathrm{N}_{2}$ & 1.56 & 12.0 & 7.8 \\
5 & $\mathrm{Et}_{2} \mathrm{O} / \mathrm{O}_{2} / \mathrm{N}_{2}$ & 1.46 & 10.0 & 10.0 \\
6 & $\mathrm{Et}_{2} \mathrm{NH}_{2} / \mathrm{O}_{2} / \mathrm{N}_{2}$ & 1.63 & 13.0 & 9.0 \\
\hline
\end{tabular}

Table 2 


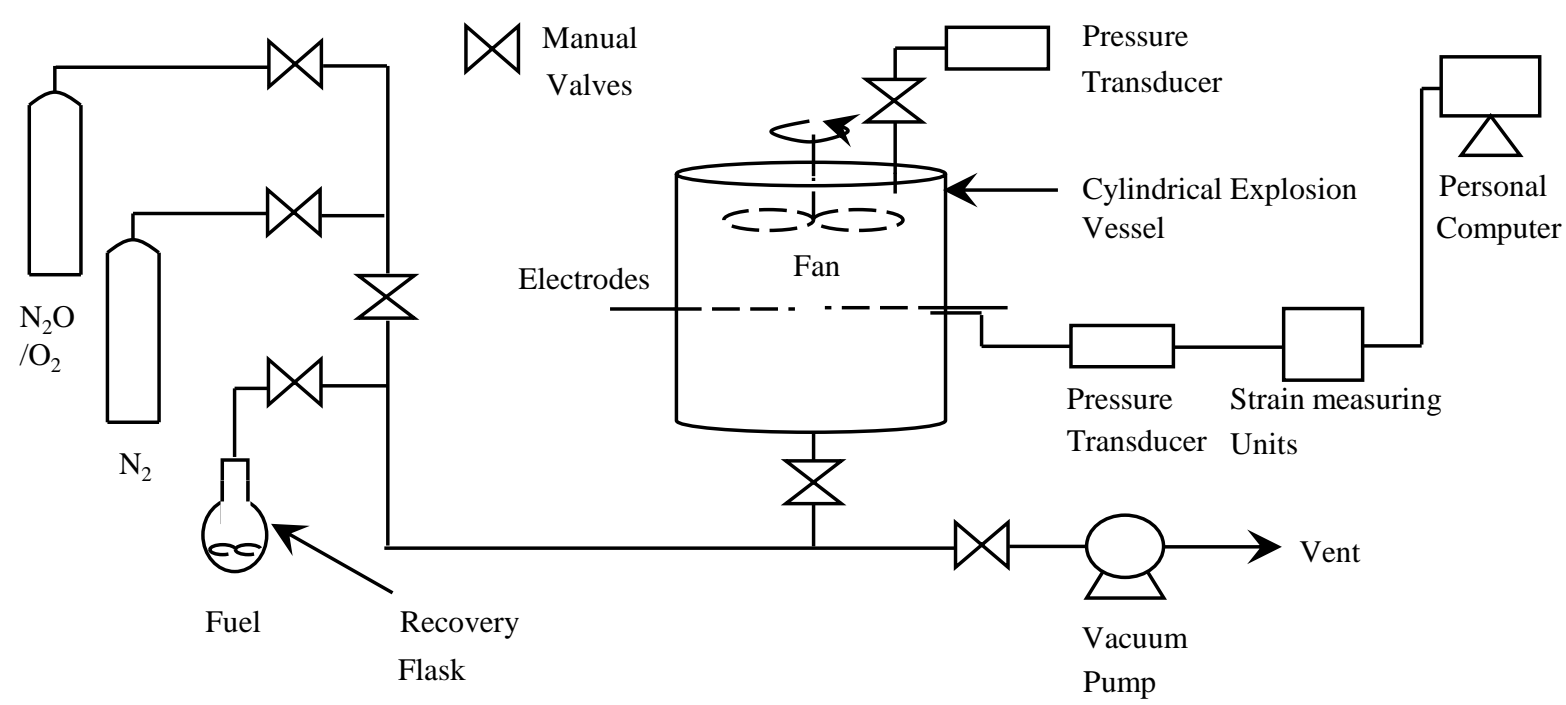




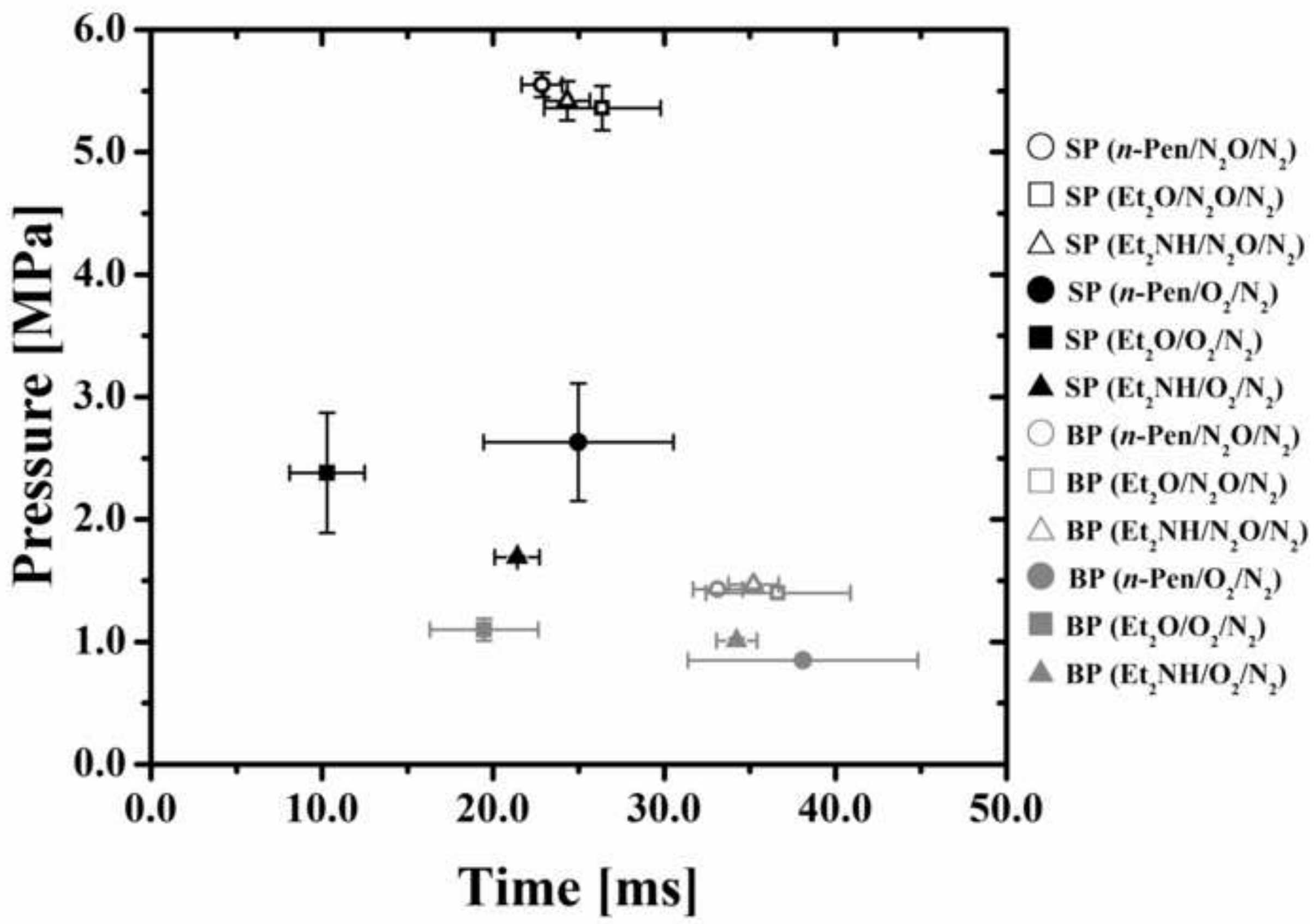




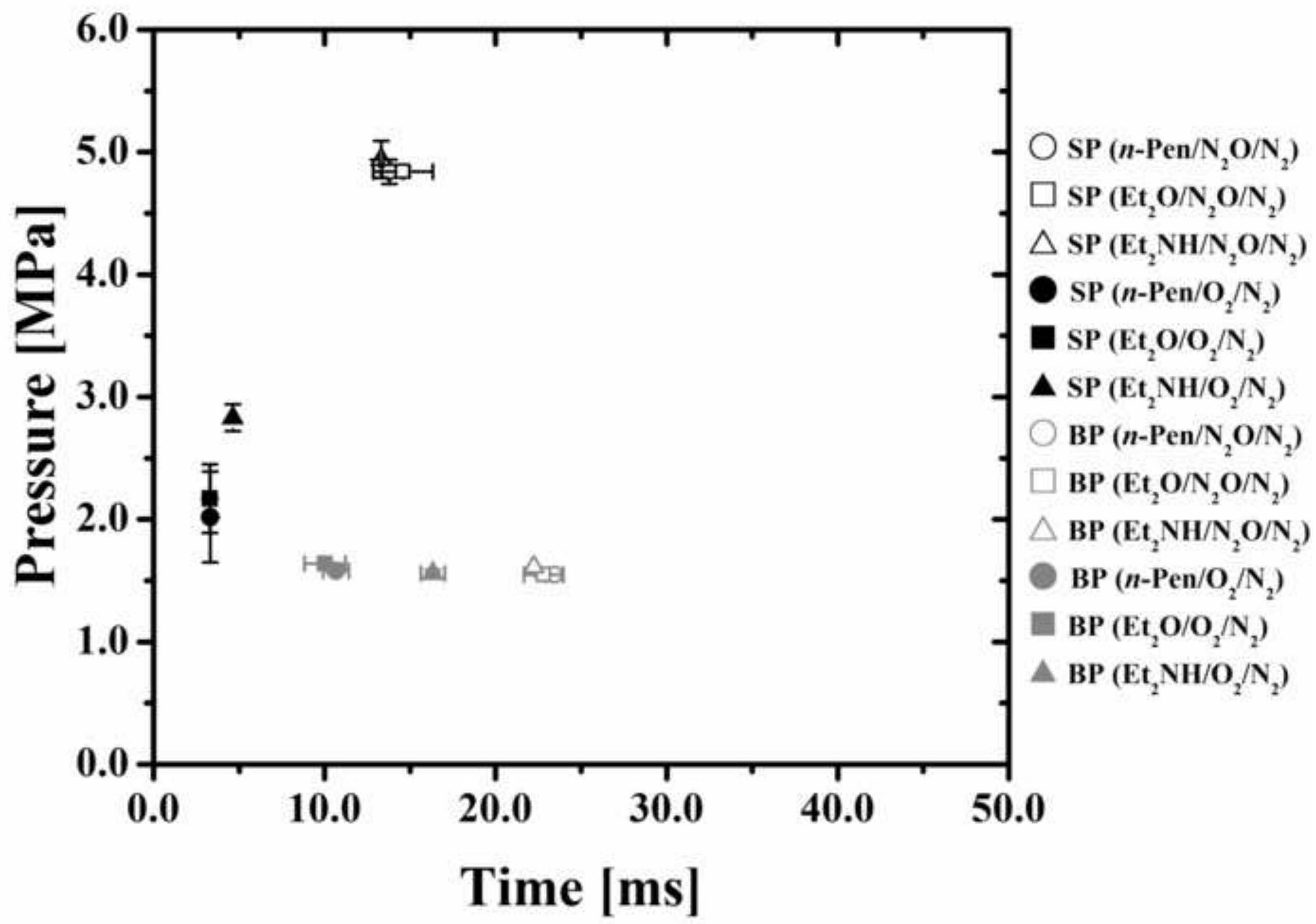




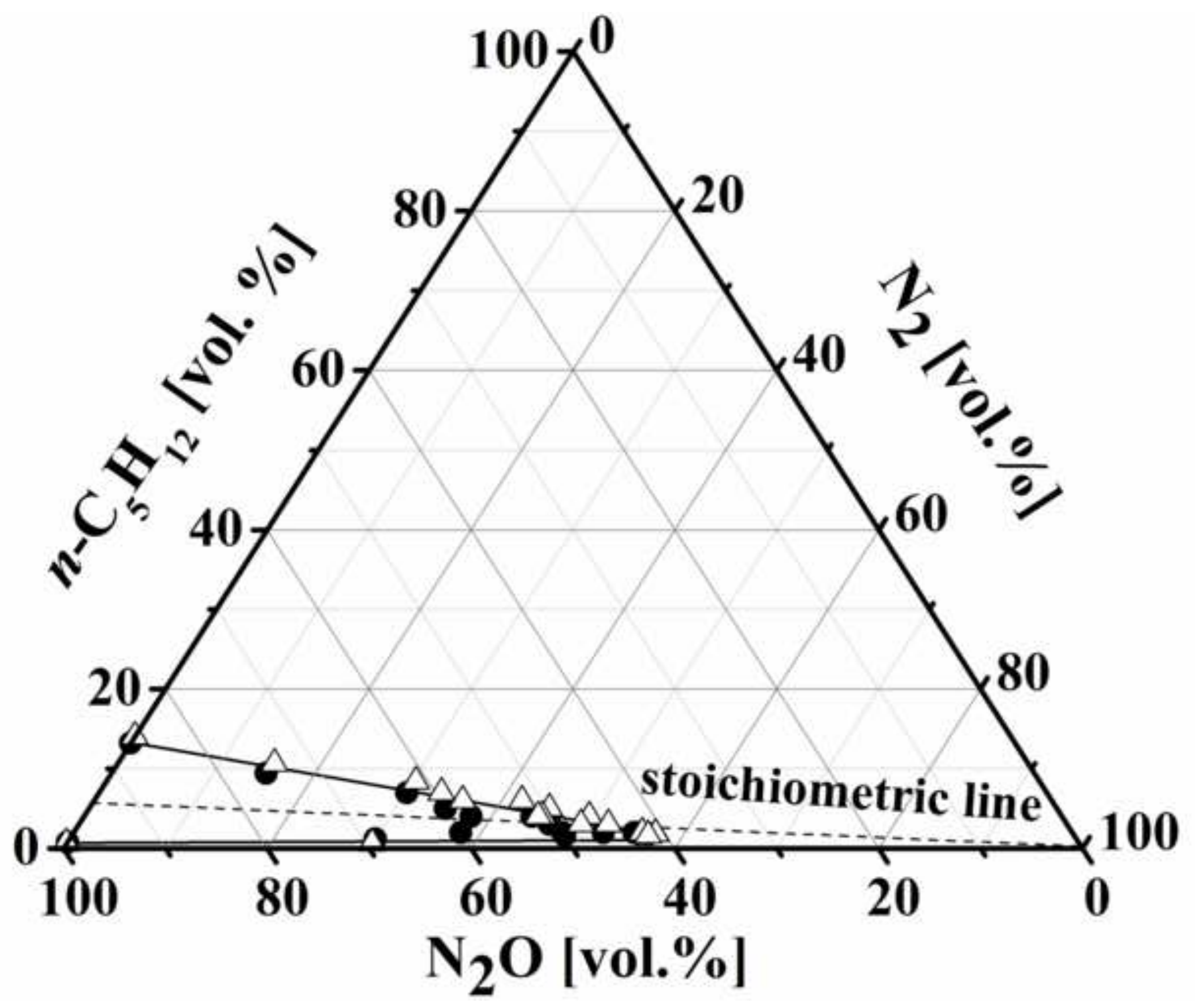




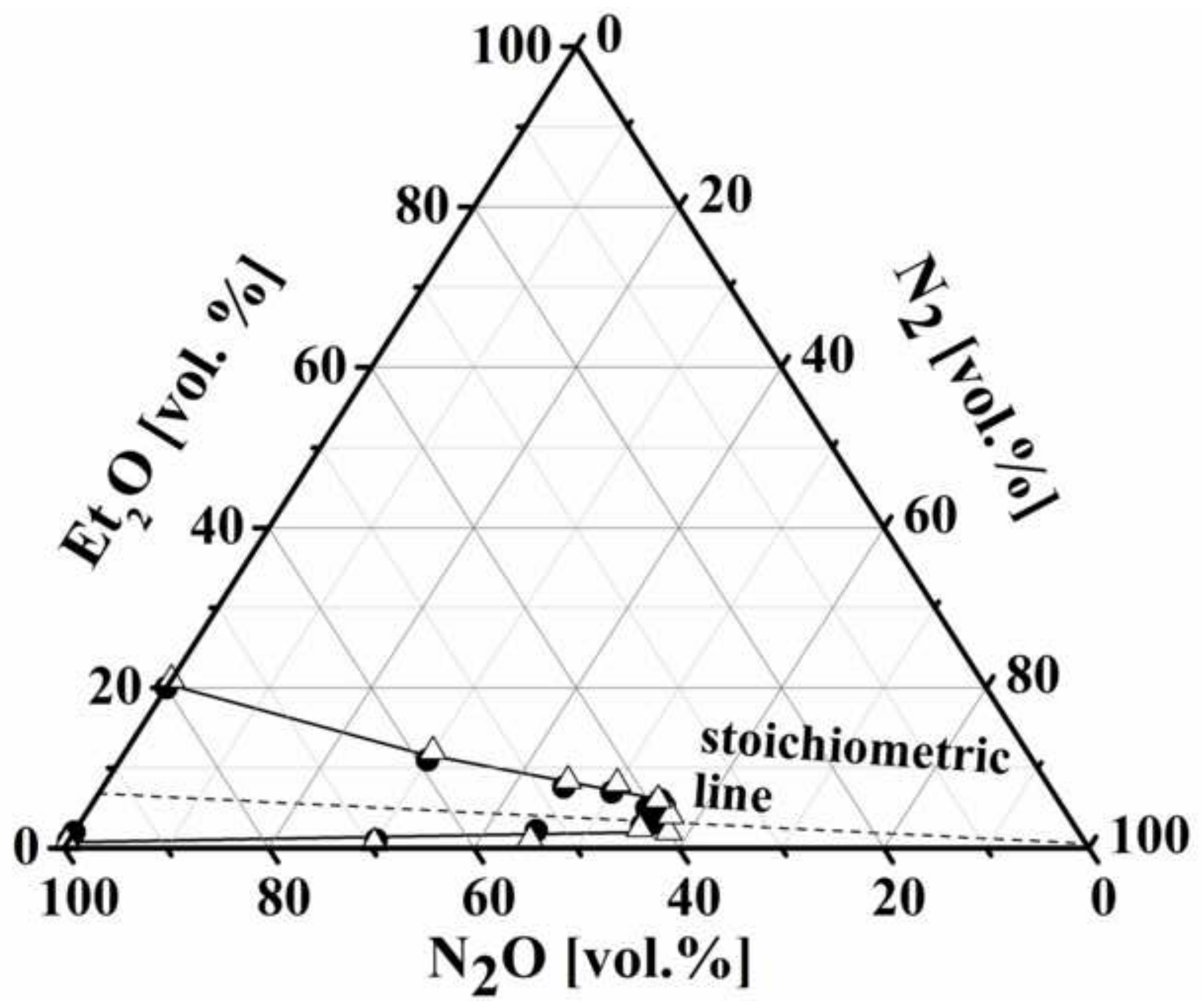




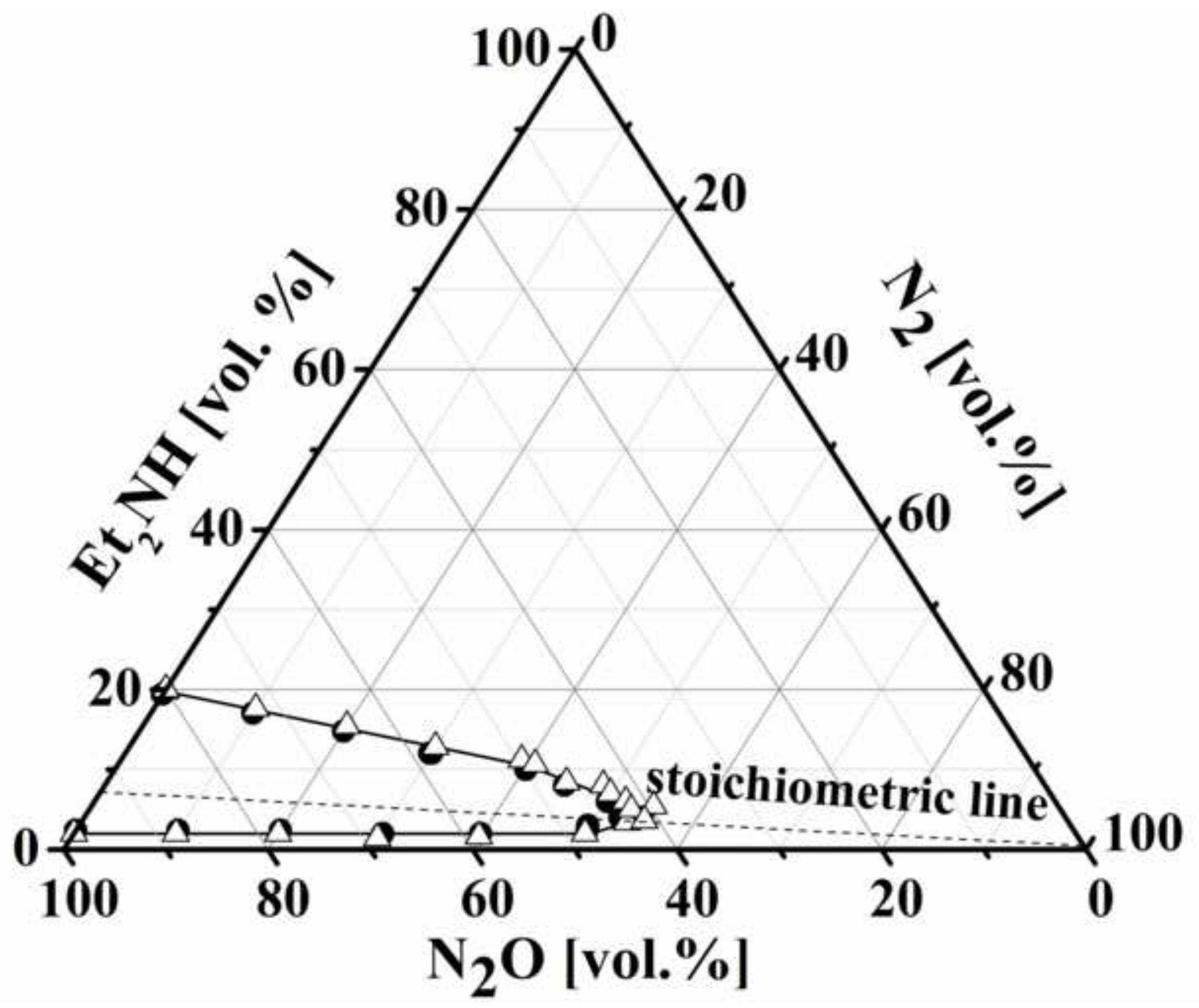




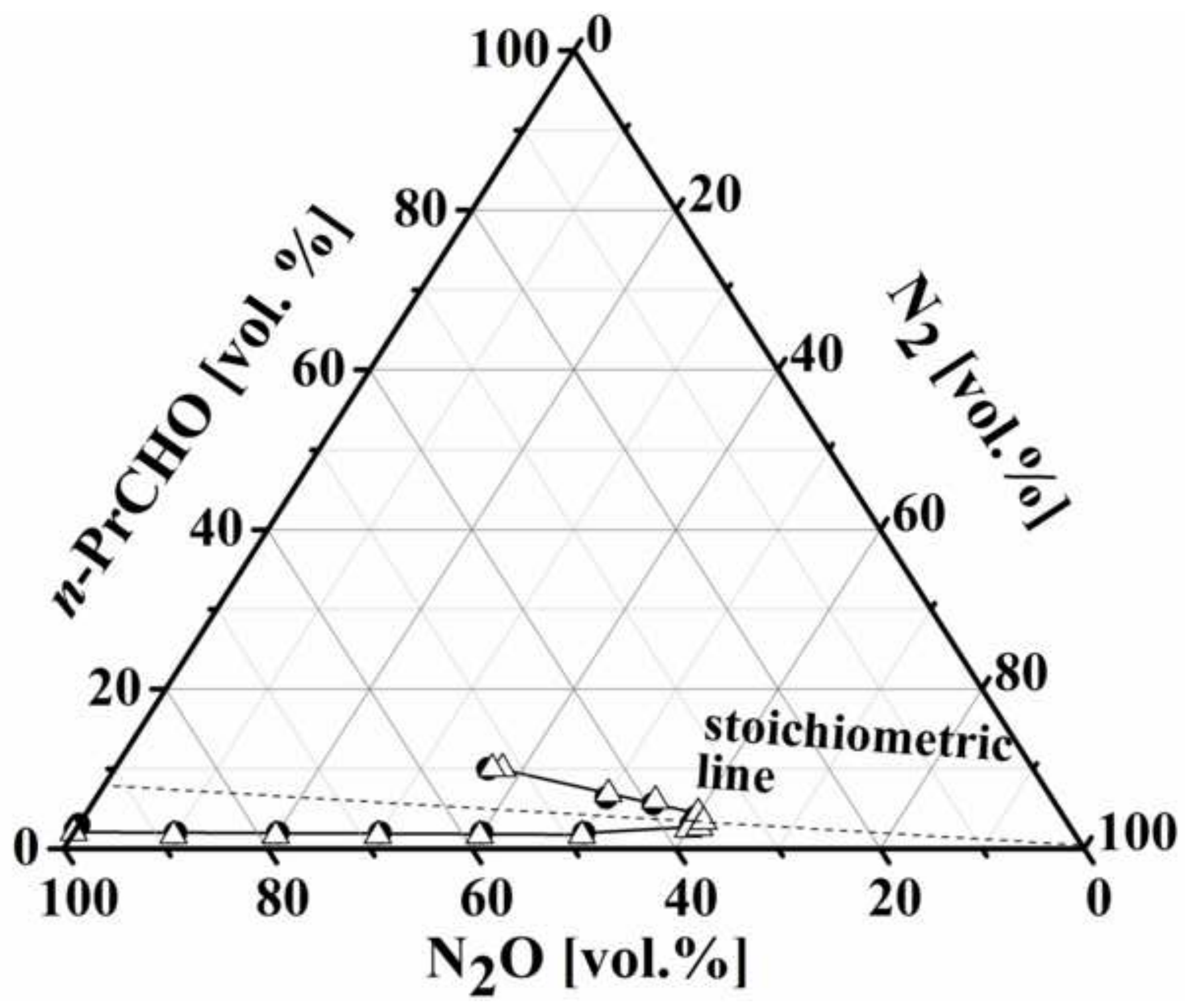




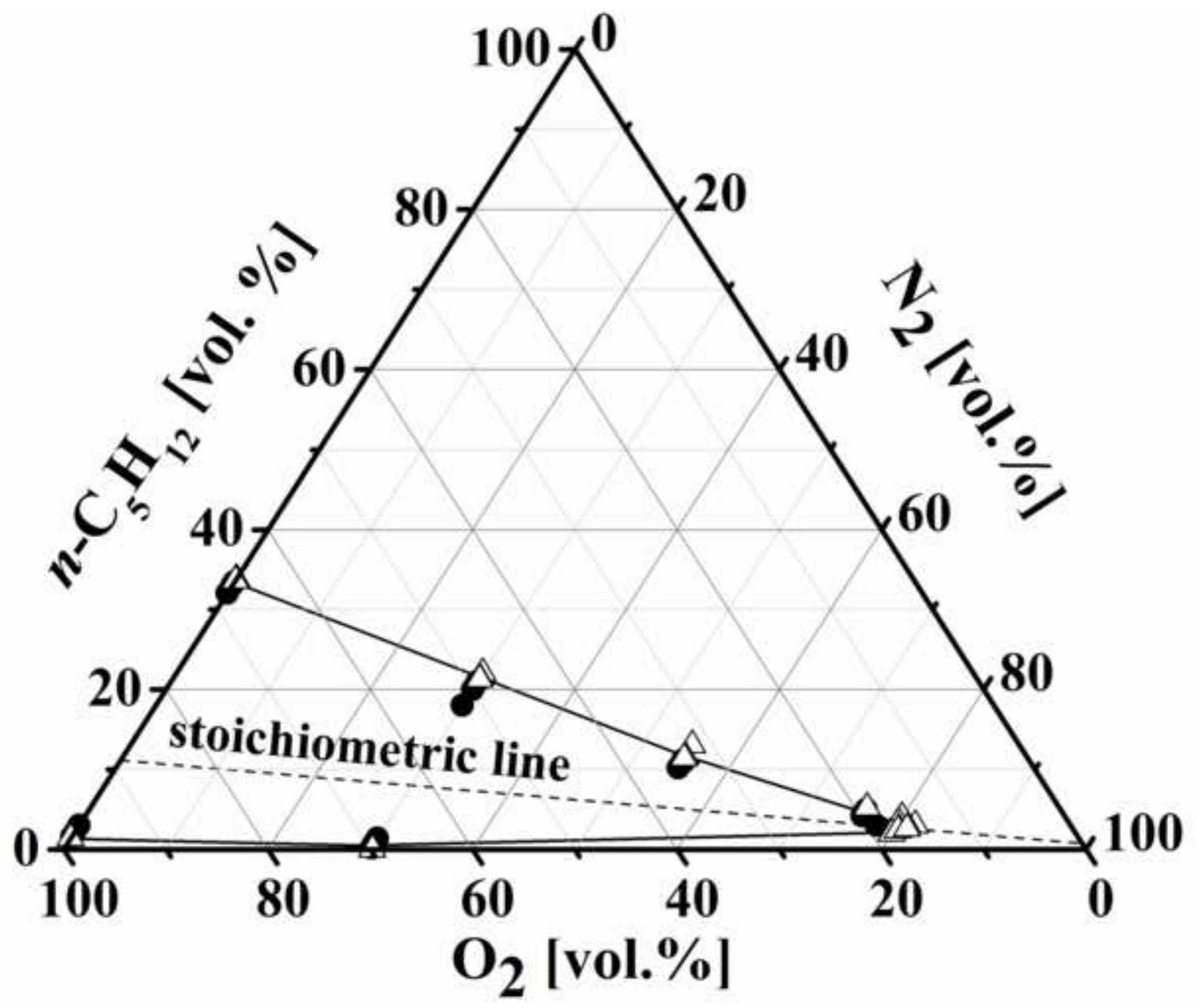




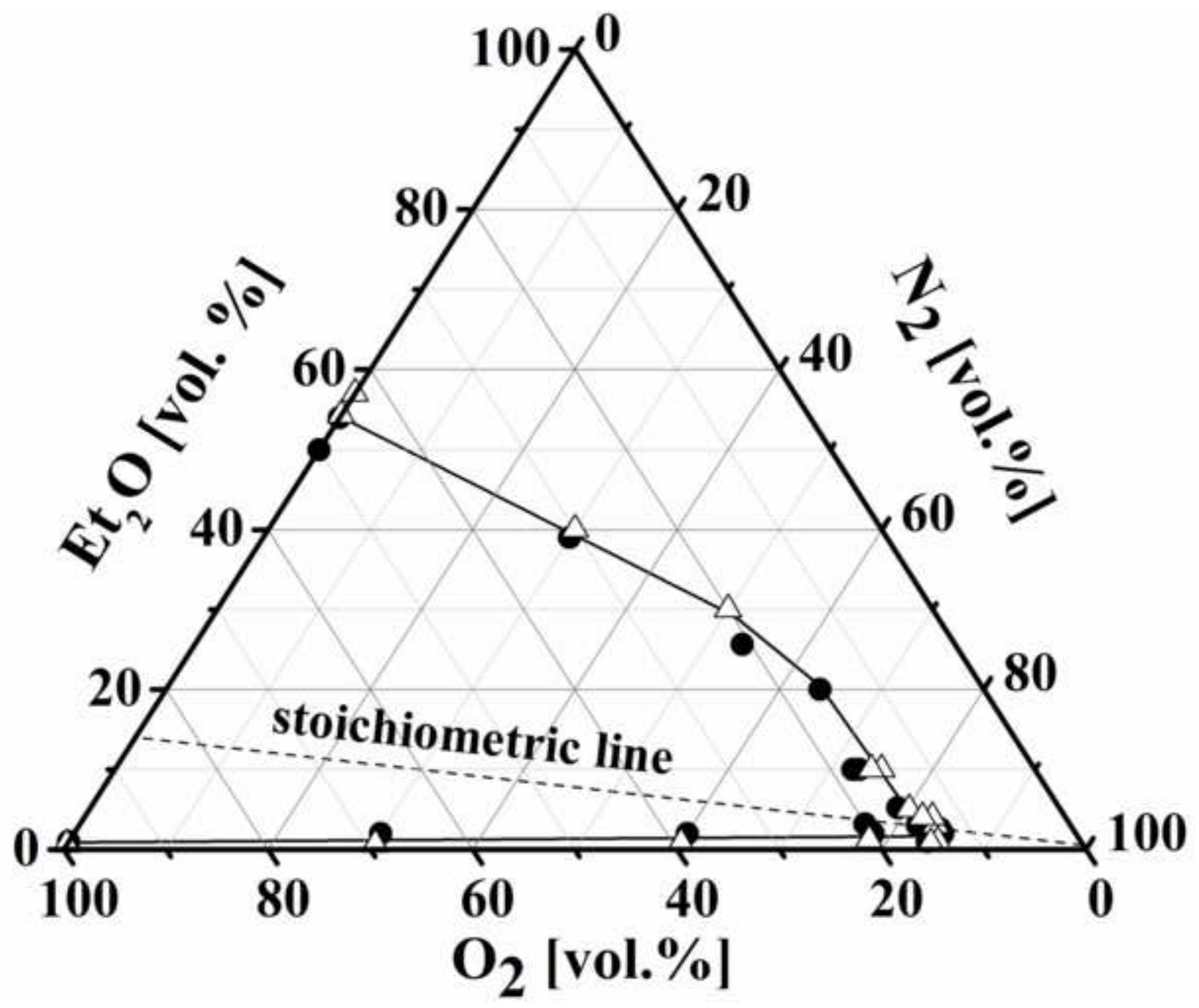




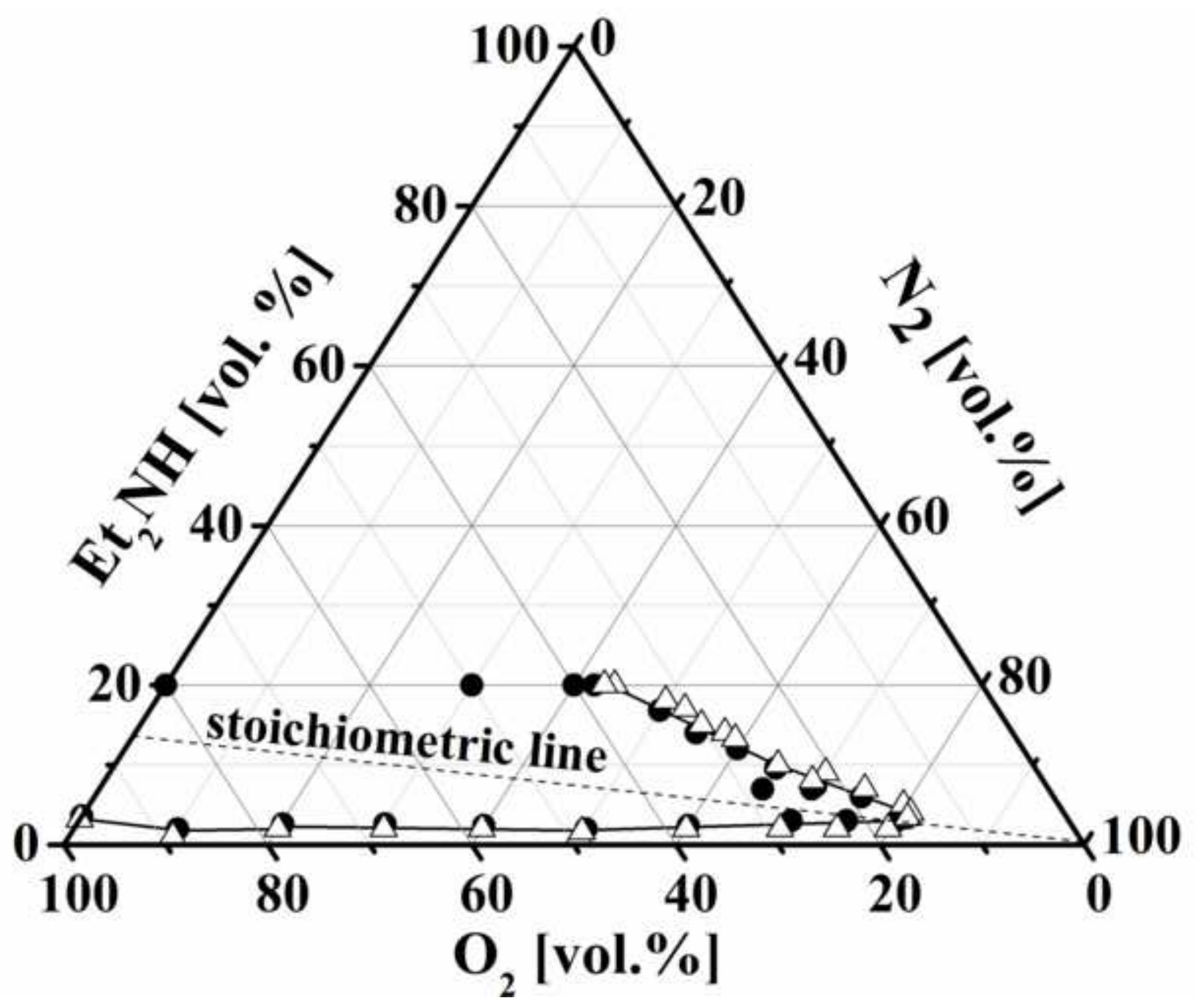




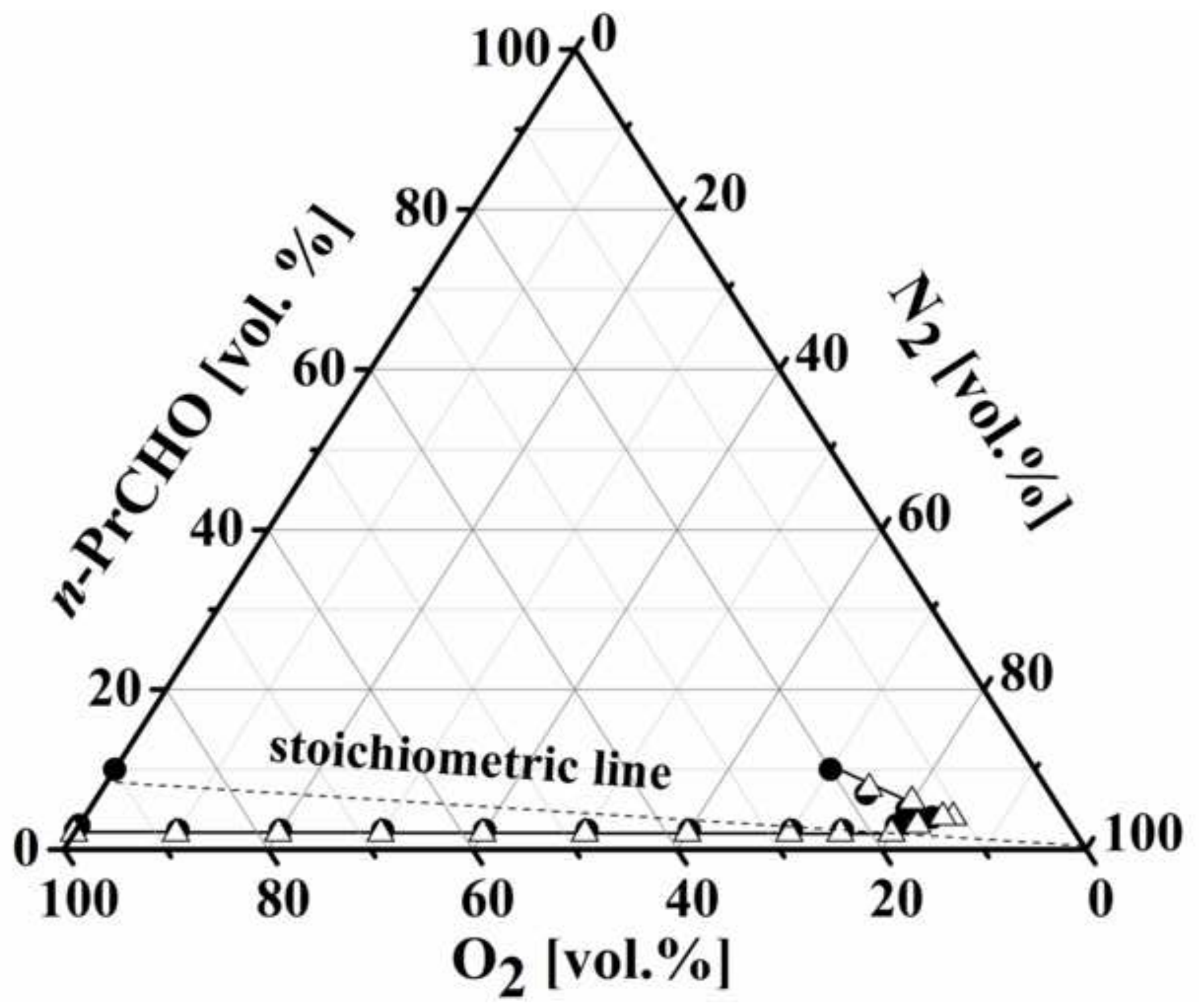




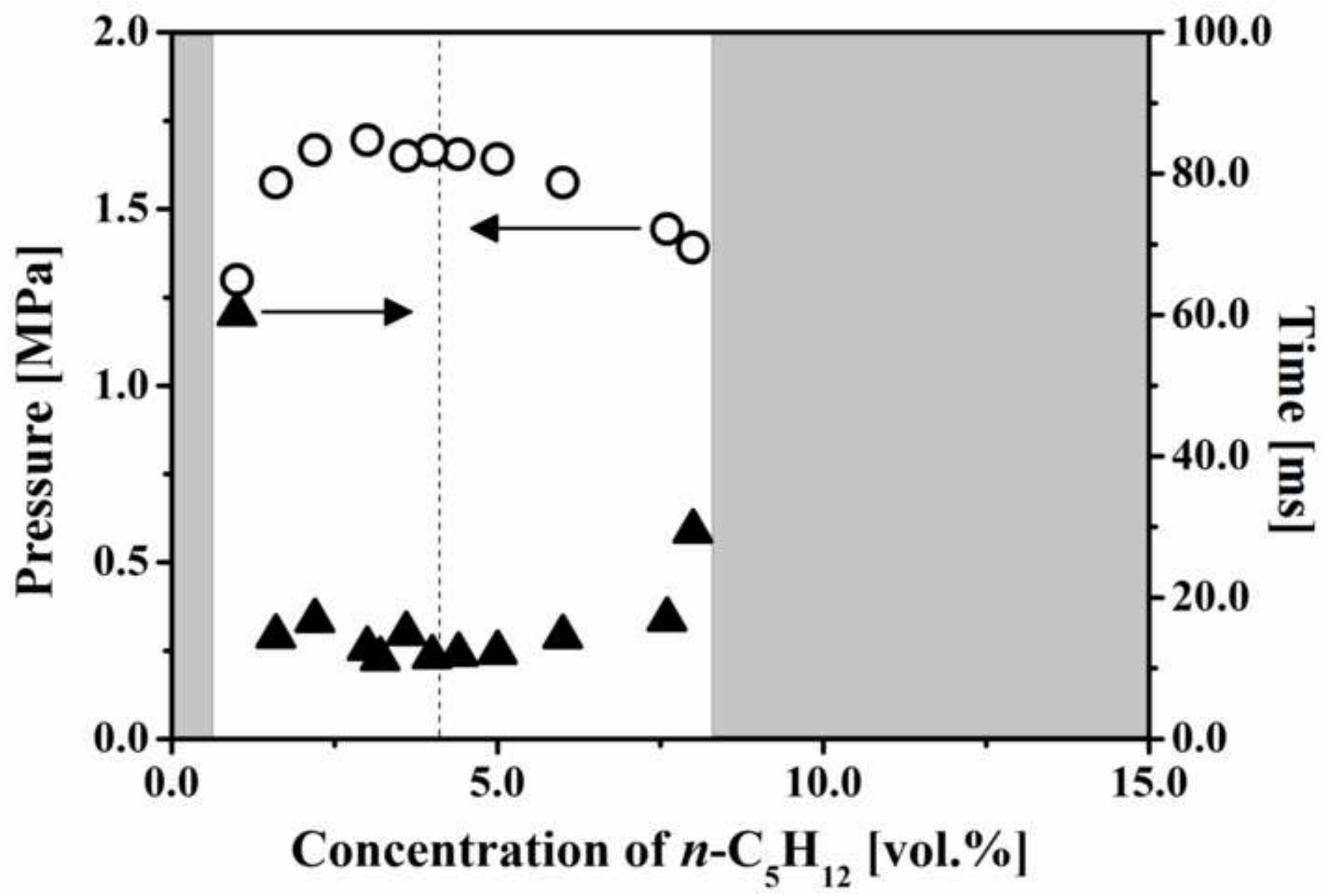




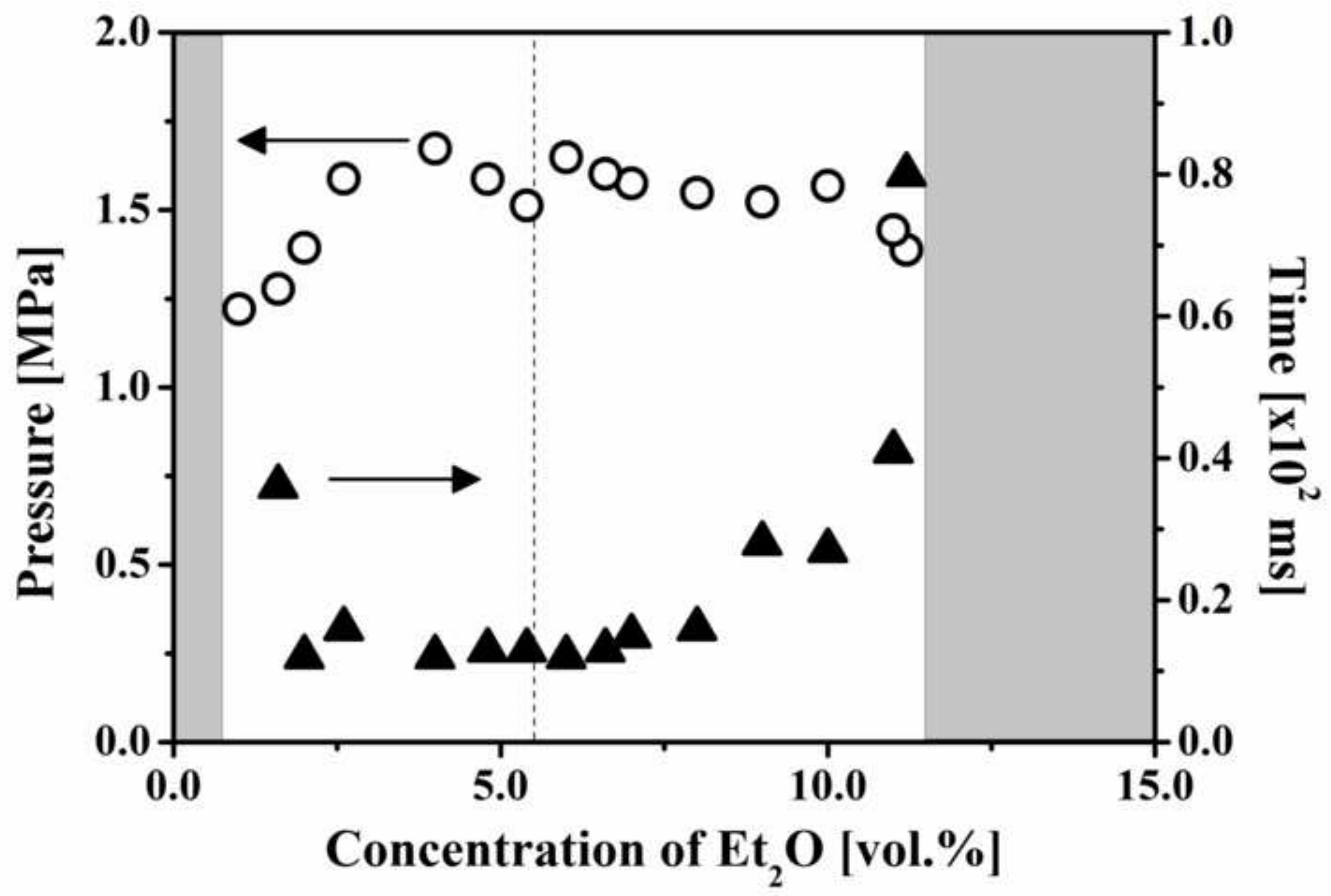




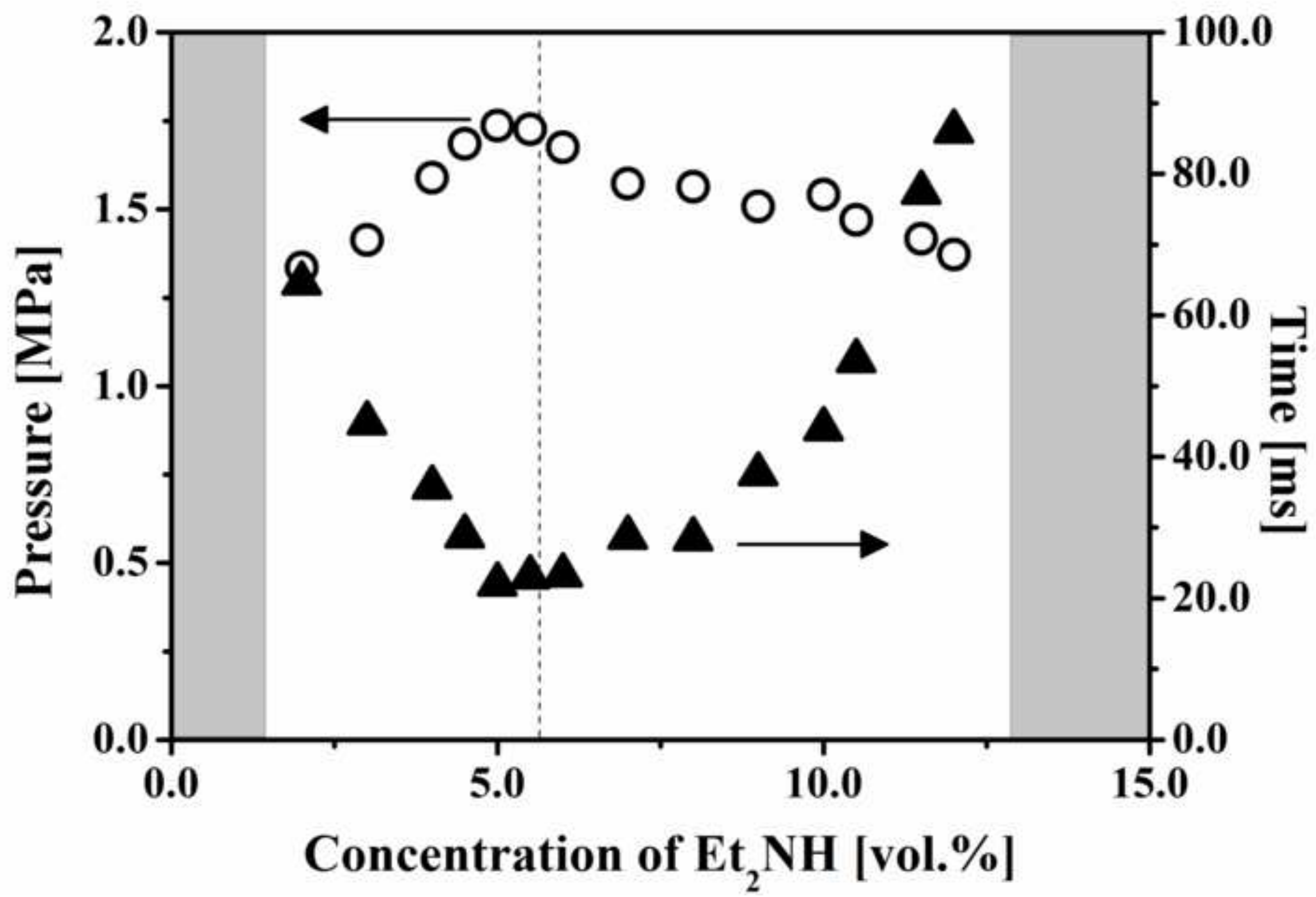




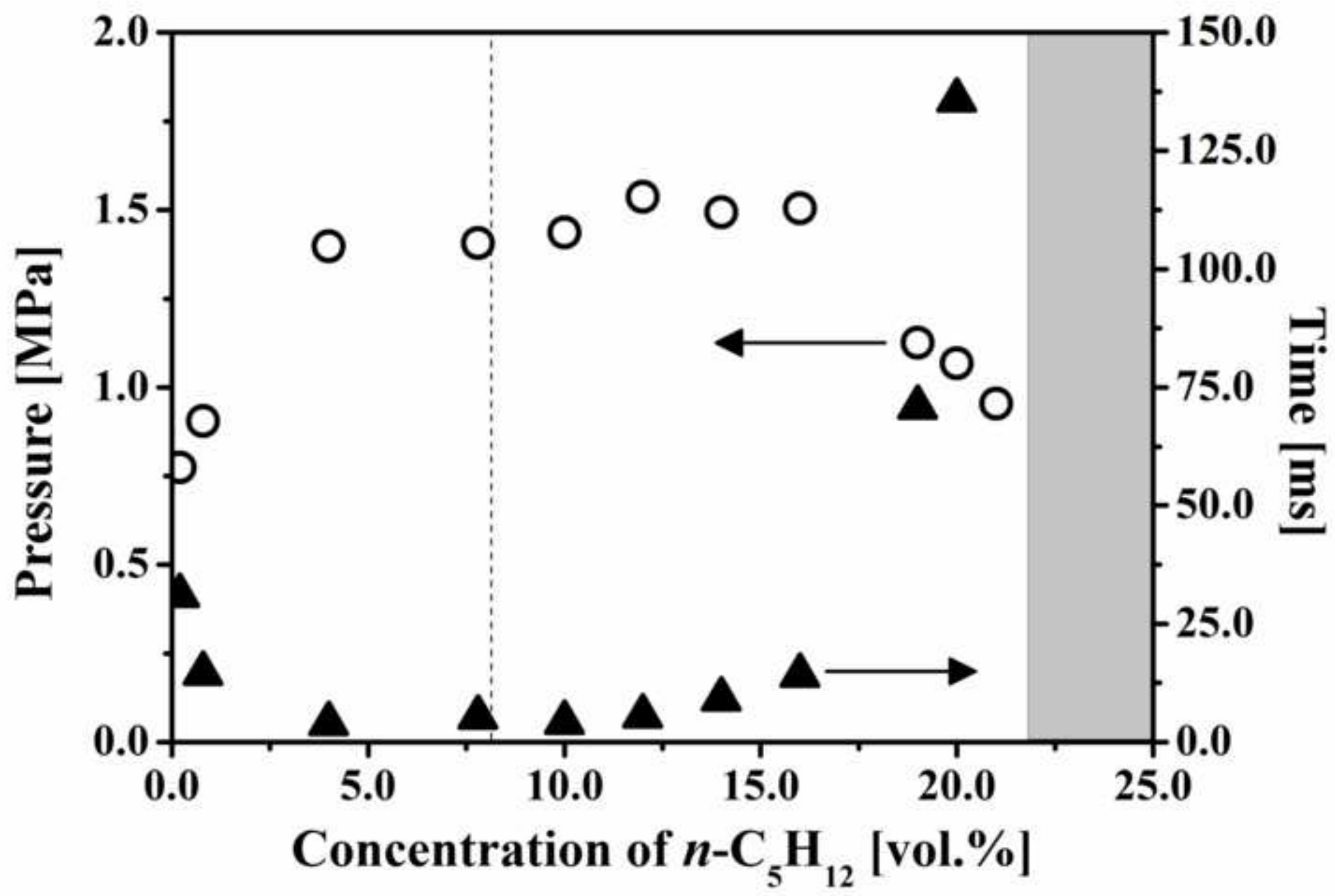




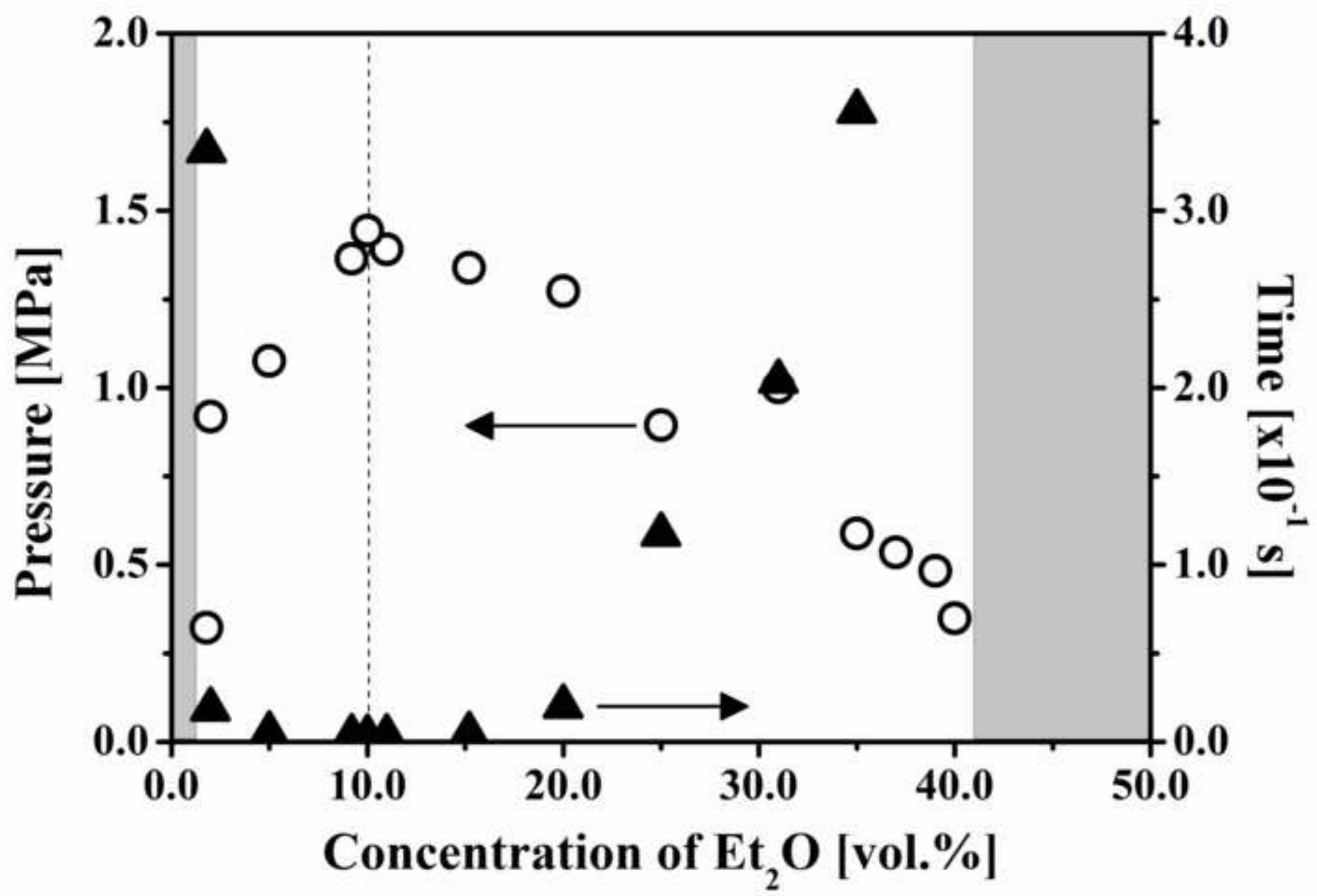




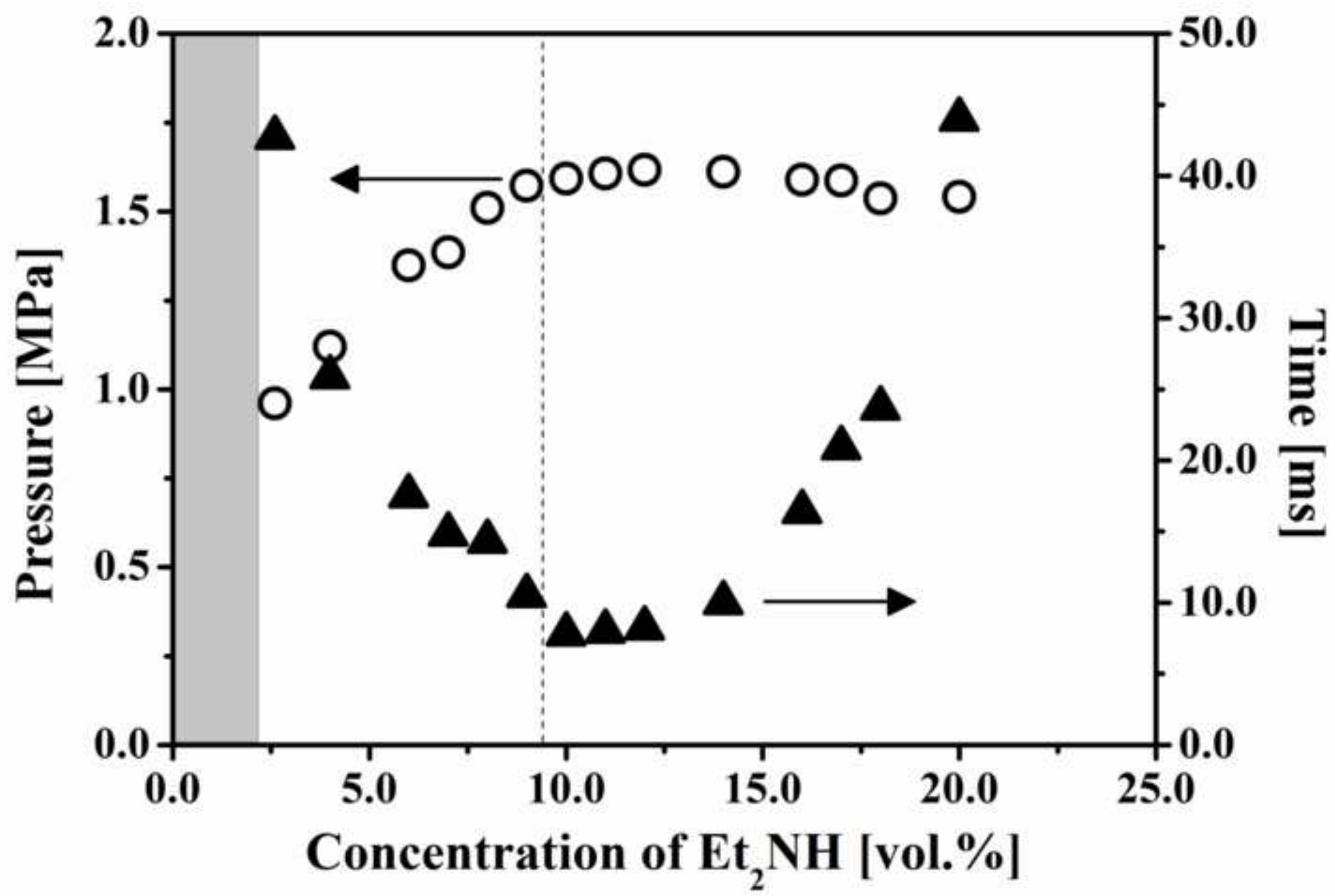


